\title{
BETONTÍPUSOK, FOGALMAK, JELÖLÉSEK, ÚJDONSÁGOK
}

\author{
AZ MSZ 4798:2016, MSZ 4798:2016/1M:2017 ÉS MSZ 4798:2016/2M:2018 \\ BETONSZABVÁNY NÉHÁNY FEJEZETÉNEK ÉRTELMEZÉSE
}

\section{RÉSZ: BETONOK SZABVÁNYOS JELÖLÉSE, BETONTERMÉK, BEDOLGOZÁSI KONZISZTENCIA, BETONTECHNOLÓGIAI MUNKAMENETTERV}

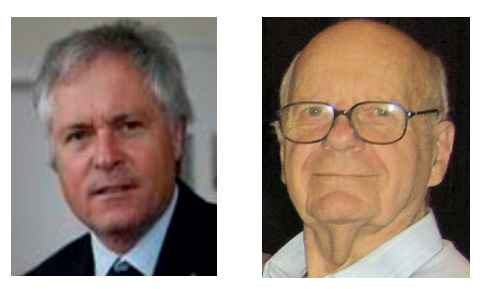

Dr. Balázs L. György - Dr. Kausay Tibor

Az MSZ EN 206-1:2002 szabványt a közelmúltban az MSZ EN 206:2014, illetve az MSZ EN 206:2013+A1:2017 szabvány váltotta fel. Ez szükségessé tette az MSZ 4798-1:2004 nemzeti alkalmazási dokumentum új szabványokra (MSZ 4798:2016 és MSZ 4798:2016/1M:2017) cserélését, és egyidejüleg lehetövé tette az újabb hazai betontechnológiai szempontok beépitését az MSZ 4798:2016 szabványba, és azok finomitását az MSZ 4798:2016/2M:2018 szabványban. E cikk e betonszabványok 2014-2018. évi változásairól szóló cikksorozat 2. része, az 1. rész a Vasbetonépités XX. évfolyam 2018/1. számának 16-22. oldalán jelent meg (Balázs L. - Kausay, 2018/1).

Kulcsszavak: szabvány, beton, beton jele, transzportbeton, előregyártott beton, szerkezeti osztály, betontermék, kiindulási beton, folyósító adalékszeres beton, konzisztencia, eltarthatóság, betontechnológiai munkamenetterv, beton nyomószilárdsági teherbírása, a fagyasztási veszteség térfogategyenlőségi átszámítási tényezője

\section{BEVEZETÉS}

Alapvetés, hogy a friss betonból vett minták próbatestjeinek vizsgálati eredményei - akkor is, ha a vizsgálatot a már megszilárdult beton próbatesteken végzik - a szóban forgó friss beton tulajdonságait, a megszilárdult betonból vett minták próbatestjeinek vizsgálati eredményei az adott korú megszilárdult beton tulajdonságait jellemzik. Minthogy a beton tulajdonságai a beton időben változó szövetszerkezetétől függenek, következik, hogy a betonra és környezetére vonatkozó fizikai, kémiai vizsgálati eredmények, adatok, valamint a felhasználásukkal képzett betonosztályok, mint például a nyomószilárdsági osztályok, testsűrüségi osztályok, konzisztencia osztályok - a karbonátosodás, a kloridok, a fagyás és olvasztósó, az agresszív vizek és folyadékok, a koptatás, a vízfelvétel és víznyomás hatását leíró - környezeti osztályok nem választhatóak el a jellemzett beton korától, aminek következtében a betonkortól a beton ezekböl összeállított jele sem függetleníthető.

A beton „,szabványos jele”, ,szabványos jelölése” kifejezés a friss betonból vett minták és a laboratóriumi sablonban készített próbatestek tulajdonságait tükröző jel, jelölés megnevezése, amely a szerkezetben vagy elemgyári sablonban megszilárdult monolit beton-, vasbeton- és feszített vasbetonszerkezet, vagy elöregyártott elem betonjának pillanatnyi (,valós idejü”) állapotáról tájékoztatást nem ad, amely jel a szerkezetbe vagy elöregyártott elembe beépített szilárd beton 28 napos, illetve átadás-átvétel kori, MSZ 4798:2016 szabvány szerinti sajátja, és amelyre a szerkezet vagy előregyártott elem szilárd betonjából származó próbatestek vizsgálati eredményének értékelése során legfeljebb csak múltidőben szabad hivatkozni. A szerke- zetbe vagy elöregyártott elembe beépített betonok vizsgálatkori tulajdonságai azok jellegétől függően a vizsgálati eredmények átlagával, szórásával, karakterisztikus (jellemző) értékének megadásával, és nem a beton szabványos jelével vagy e jel tagjaival írhatóak le.

Az MSZ 4798:2016 betonszabvány 1. fejezetében írják, hogy „Ez a szabvány a betonra mint termékre vonatkozik, és nem vonatkozik a szerkezetbe már beépített betonra"; és az MSZ EN 1992-1-1:2010 Eurocode 2 méretezési szabvány 3.1.2. szakaszában, hogy az Arrhenius-féle összefüggést „,egy nem megfelelő referenciaszilárdság visszamenőleges igazolására általában nem szabad alkalmazni, még az utószilárdullás figyelembevételével sem". Ugyanez vonatkozik a nyomószilárdsági osztály jelére is, amely a beton jelének legföbb megtestesítője.

\section{BETONOK SZABVÁNYOS JELÖ- LÉSE}

A beton szabványos jelölése a beton legfontosabb elérendő tulajdonságait összefoglaló alapvető, irányt mutató „adathordozó", amely a vasbetonépítményt létrehozó beruházó, építtető, szerkezettervezö, betontechnológus, betongyár, betonelemgyár, kivitelező és megfelelőség tanúsító között nélkülözhetetlen betontechnológiai kapcsolatot teremt.

Az MSZ 4798:2016 szabvány szerint a beton jele a következő tagokból áll (a beton jele tagjainak sorszámát fekete körben tüntettük fel, ha azok szerepeltetése kötelezö, és fehér körben, ha azok a beton jelében feltételesen szerepelnek): 
- Nyomószilárdsági osztály betủjellel és két számjellel (számértékkel) kifejezett jele, például szokványos (közönséges, normál) beton esetén: C30/37, könnyübeton esetén: LC30/33.

Megjegyzések:

- Nehézbeton esetén például a HC betủjel használatát - következetessége és gyakorlatiassága ellenére - a szabvány nem írja elö, így a gyakorlatban helyette általában a $C$ betűjelet alkalmazzák.

- A nyomószilárdsági osztály jelében szereplő első, a tört vonal elött álló számjel a $\varnothing 150 \times 300$ mm méretü, laboratóriumi sablonban készített, kizsaluzás után végig víz alatt tárolt és vizes állapotú, nem csiszolt nyomott felületü, 28 napos korú beton próbahengerek nyomószilárdságának $f_{\text {ck,cyl }}$ jelủ elöírt karakterisztikus (jellemzö) értéke, $\mathrm{N} / \mathrm{mm}^{2}$ (MPa) mértékegységben.

- A nyomószilárdsági osztály jelében szereplő második, a tört vonal után álló számjel a $150 \mathrm{~mm}$ élhosszúságú, laboratóriumi sablonban készített, kizsaluzás után végig víz alatt tárolt és vizes állapotú, eredeti sablonoldali nyomott felületü, 28 napos korú beton próbakockák nyomószilárdságának $f_{\text {ck,cube }}$ jelü elöírt karakterisztikus (jellemzö) értéke, $\mathrm{N} / \mathrm{mm}^{2}$ (MPa) mértékegységben.

- Egyazon elöírt karakterisztikus (jellemzö) érték vagy nyomószilárdsági osztály az alulmaradási tágasságra vonatkozó szabványintézkedéstől függően más-más előírt átlagos nyomószilárdsági értéket takarhat, mint azt például az MSZ EN 1992-1-1:2010 Eurocode 2 és MSZ EN 206:2013+A1:2017, illetve az utóbbit követő MSZ 4798:2016 szabvány O mellékletének példája mutatja. Az MSZ 4798:2016 szabvány O melléklete szerinti nagyobb elfogadási valószínűséghez (mintegy 70\%), illetve kisebb alulmaradási tágassághoz kisebb átlagos nyomószilárdság tartozik, mint az MSZ EN 1992-1-1:2010 Eurocode 2 szabvány szerinti kisebb elfogadási valószínűséghez (mintegy $50 \%$ ), illetve nagyobb alulmaradásui tágassághoz (Kausay, 2006/2, 2013).

D $^{+} \quad$ Ha a nyomószilárdságot közel $50 \%$ elfogadási valószínüség mellett - az MSZ 4798:2016 szabvány P melléklete szerint, az Eurocode 2 szabvány alapján - értékelik és ellenőrzik, akkor függetlenül a nyomószilárdság nagyságától a nyomószilárdsági osztály $\mathbf{0}$ szerinti jele után mindig fel kell tüntetni az 50\%-os elfogadási valószínűségre utaló $\mathrm{AC}_{50}(\mathrm{H})$ kísérőjelet, például: $\mathrm{C} 30 / 37$ $\mathrm{AC}_{50}(\mathrm{H})$.

Megjegyzés:

$\mathrm{Az} \mathrm{AC}_{50}(\mathrm{H})$ kíséröjelet szóköz (space) nélkül kötőjellel írjuk a nyomószilárdsági osztály jele után, ezzel is hangsúlyozva e jelek egymáshoz tartozását, eszmei elválaszthatatlanságát.

(2) Ha a beton könnyübeton, akkor a szilárd könnyübeton testsürüségi osztályának jele, például: $\rho_{\mathrm{LC}} 1,8$.

3 Környezeti osztály vagy osztályok jele, például: XC4, vagy több környezeti osztály esetén: XC4-XF1-XA2. Megjegyzések:

- Ha a környezeti osztályhoz tartozó ajánlott legkisebb nyomószilárdsági osztály csak a beton 28 napos kora után, az utószilárdulás folyamán, 90 napos korra teljesül - és ezt írásban igazolják -, akkor azt a környezeti osztály jelében „,90” alsó indexszel kell jelezni. Például: $\mathrm{XD}{ }_{90}(\mathrm{H})$. Ebben az esetben a beton jelében meg kell adni az alkalmazandó cement jelét is.

- Ha valamely környezeti osztályt magyar nemzeti szabvány vezeti be, akkor a környezeti osztály jelében fel kell tüntetni Magyarország nevének rövid jelét $(\mathrm{H})$, például: $\mathrm{X} 0 \mathrm{~b}(\mathrm{H}), \mathrm{X} 0 \mathrm{v}(\mathrm{H}), \mathrm{XD} 2_{90}(\mathrm{H}), \mathrm{XF} 2(\mathrm{H})$, XA5(H), XK1(H), XV0(H), XV1(H).

Ezt a szabályt kell alkalmazni a magyar szabványok bevezette egyéb jelölések esetén is, olykor alsó indexbe írva a $H$ betủt, például: $f_{c k, c u b e, H}$ (MSZ 4798:2016/2M:2018).

Ha a jelet másik magyar szabályozó irat vezeti be, akkor ugyanígy kell eljárni.

(4 Adalékanyag névleges legnagyobb szemnagyságának a számértéke, például: $24 \mathrm{~mm}$.

(5) Ha a beton adalékanyaga nem homokos kavics, az adalékanyag megnevezése, amellyel a beton készül, például: zúzottkő és megadva annak fajtáját (például bazalt zúzottkő, andezit zúzottkő, dolomit zúzottkő stb.), vagy barit, duzzasztott agyagkavics stb.

( Konzisztencia osztály jele, például: F3; vagy a konzisztencia jele a mérőszám határértékeivel, például: F3 (420-480 mm), vagy a konzisztencia jele a mérőszám

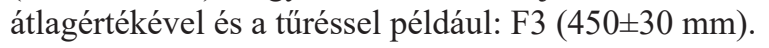
Megjegyzések:

- A konzisztencia osztály jele a kivitelezővel kötendő szerződésben akkor is egyértelmüen (egyetlen jellel) rögzítendő, ha a beton jelének megadásakor vagy a betontervezés során a konzisztencia mérési módszer mibenléte még nem volt ismert, és az elöíró vagy tervező a konzisztencia jelét két mérési módszerhez illesztve is megadta, például terülésméréssel: F3 és alternatívaként roskadásméréssel: S2.

- Az önterülö-öntömörödő beton konzisztenciáját az MSZ 4798:2016 szabvány öntömörödö betonokra vonatkozó konzisztencia osztályainak jelével kell megadni.

(7) Ha a betonnak a cement tömegére vonatkoztatott megengedett kloridiontartalma 0,2 tömeg\% - útbeton esetén 0,4 tömeg\% (MSZ EN 13877-1:2013) - akkor azt a beton jelében nem kell megadni, ha ennél kisebb, akkor a megengedett kloridiontartalom jelét a beton jelében szerepeltetni kell, például feszített vasbeton esetén: $\mathrm{C} \ell 0,10$.

(8) Ha a kiíró követelményként megadja a cement minőségét és esetleg a II. típusú kiegészitöanyag minőségét is, akkor annak, illetve azok jelét a beton jelében fel kell tüntetni (például: CEM I 42,5 vagy CEM I 42,5 - Szilikapor).

(9) Ha a beton tervezési élettartama 50 év, akkor a tervezési élettartamot a beton jelében nem kell megadni, ha ettől eltérő (például 100 év), akkor azt a beton jelében fel kell tüntetni.

(1) A beton jele végén szerepeltetni kell a szabvány vagy szabványok jelzetét az évszámmal együtt, például: MSZ 4798:2016; vagy MSZ 4798:2016, MSZ 4798:2016/2M:2018

A betonjel tagjait egymás után, két szóköz (space) közé írt gondolatjel (hosszú kötőjel) közbeiktatásával tüntetjük fel,

- ha a beton nyomószilárdságát mintegy $70 \%$ elfogadási valószinüség mellett értékelik és megfelelőségét az MSZ4798:2016 szabvány O melléklete szerint ellenőrzik, akkor például így: 0 - (2) - 3 - (4) - (5) - $6-$ - (7) - (8) - (9) - (1)

- ha a beton nyomószilárdságát közel $50 \%$ elfogadási valószínüség mellett értékelik és a megfelelöségét - az Eurocode 2 szabvány előírásához közelítve - az MSZ 4798:2016 szabvány $P$ melléklete szerint ellenőrzik, akkor például így:

$\boldsymbol{D}^{+}-$(2) - 3 - 4 - (5) - 0 - (7) - (8) - (9) - (1)

A tervezői müszaki leírásnak, a betontechnológiai elöírásnak, 
illetve a beton megrendelő és szállítási dokumentumának a beton jelén kívül tartalmaznia kell minden olyan követelményt, amelyet az építmény vagy a beton készítésével, illetve átadás-átvételével kapcsolatban a beton jelén kívül elöírnak. Ilyen például a betont befogadó építmény szerkezeti osztálya, a beton nyomószilárdsága karakterisztikus (jellemző) értékének kiszámításához szükséges alulmaradási tényező fajtája, illetve bármilyen más, a beton minőségével kapcsolatos egyéb követelmény (például szulfátállóság, szikramentesség, a figyelembe vett müszaki elöírás vagy irányelv jelzete évszámmal együtt stb.).

Példák a beton MSZ 4798:2016 szabvány szerinti jelére:

1. példa: Annak a C30/37 nyomószilárdsági osztályú betonnak a jele, amelyből építményen belüli vasbeton keretszerkezet épül, névleges legnagyobb szemnagysága $D_{\max }=24 \mathrm{~mm}$, konzisztenciája képlékeny és terülési mértéke 420-480 mm közé esik, tehát konzisztencia osztálya F3, a következő:

C30/37 - XC3 - 24 - F3 - MSZ 4798:2016

2. példa: Annak a C30/37 nyomószilárdsági osztályú betonnak a jele, amelynek nyomószilárdságát $50 \%$ elfogadási valószínüség mellett értékelték, és amelyből csúszózsalus építésmóddal CEM I 42,5 N-SR 0 szulfátálló portlandcementés szilikaportartalmú vasbeton siló épül, névleges legnagyobb szemnagysága $D_{\max }=24 \mathrm{~mm}$, konzisztenciája a kissé képlékeny és a képlékeny határán van és tömörítési mértéke 1,11-1,25 közé esik, tehát konzisztencia osztálya $\mathrm{C} 2$, megengedett kloridiontartalma a cement tömegszázalékában kifejezve 0,2 tömeg\%, a következö:

$\mathrm{C} 30 / 37-\mathrm{AC}_{50}(\mathrm{H})-\mathrm{XC} 4-\mathrm{XD} 1-\mathrm{XF} 1-\mathrm{XA} 5(\mathrm{H})-\mathrm{XK} 1(\mathrm{H})-$ 24 - C2 - C 0,20 - CEM I 42,5 NSR 0 - Szilikapor - MSZ 4798:2016 és MSZ 4798:2016/2M:2018

3. példa: Annak a C30/37 nyomószilárdsági osztályú, légbuborékképző adalékszerrel gyártott betonnak a jele, amelynek nyomószilárdságát $50 \%$ elfogadási valószínüség mellett értékelték, és amelyből fagy és sózás hatásának kitett vasbeton híd pályaszegélye készül, névleges legnagyobb szemnagysága $D_{\max }=32 \mathrm{~mm}$, konzisztenciája képlékeny és terülési mértéke $450 \pm 30 \mathrm{~mm}$, konzisztencia osztálya F3, a következő:

$\mathrm{C} 30 / 37-\mathrm{AC}_{50}(\mathrm{H})-\mathrm{XC} 4-\mathrm{XF} 4-\mathrm{XK} 2(\mathrm{H})-32-\mathrm{F} 3-$ MSZ 4798:2016 vagy

$\mathrm{C} 30 / 37-\mathrm{AC}_{50}(\mathrm{H})-\mathrm{XC} 4-\mathrm{XF} 4-\mathrm{XK} 2(\mathrm{H})-32-\mathrm{F} 3(450 \pm 30$ $\mathrm{mm}$ ) - MSZ 4798:2016

4. példa: Annak a C35/45 nyomószilárdsági osztályú betonnak a jele, amelynek az erőtani méretezés szerint szükséges nyomószilárdsági karakterisztikus (jellemzö) értéke $f_{\text {ck,cyl }}=35$ $\mathrm{N} / \mathrm{mm}^{2}$ (a környezeti hatás miatt $\mathrm{C} 30 / 37$ nyomószilárdsági osztályú beton is megfelelne) és nyomószilárdságát $50 \%$ elfogadási valószínüség mellett értékelték, amely betonból esőtől védett helyen álló feszített vasbeton gerenda készül, névleges legnagyobb szemnagysága $D_{\max }=24 \mathrm{~mm}$, konzisztenciája képlékeny és terülési mértéke 420-480 mm közé esik, tehát konzisztencia osztálya F3, CEM I 52,5 szilárdsági osztályú portlandcementtel készül, tervezési élettartama 100 év, a következő:

$\mathrm{C} 35 / 45-\mathrm{AC}_{50}(\mathrm{H})$ - XC3 - 24 - F3 - CEM I 52,5 - 100 év MSZ 4798:2016 vagy

$\mathrm{C} 35 / 45-\mathrm{AC}_{50}(\mathrm{H})-\mathrm{XC} 3-24-\mathrm{F} 3(420-480 \mathrm{~mm})$ - CEM I 52,5 - 100 év - MSZ 4798:2016

5. példa: Annak a C40/50 nyomószilárdsági osztályú, légbuborékképző adalékszer nélkül gyártott fagy- és olvasztósóálló, kopásálló bazaltbetonnak a jele, amelynek nyomószilárdságát $50 \%$ elfogadási valószínűség mellett értékelték, és amelyből fagy és sózás hatásának, valamint koptatóhatásnak kitett beton térburkolat készül, névleges legnagyobb szemnagysága $D_{\max }=$ 32 mm, konzisztenciája képlékeny és terülési mértéke 420-480 mm közé esik, konzisztencia osztálya F3, a következő: $\mathrm{C} 40 / 50-\mathrm{AC}_{50}(\mathrm{H})-\mathrm{XC} 4-\mathrm{XF} 4(\mathrm{H})-\mathrm{XK} 3(\mathrm{H})-32$ - bazalt zúzottkő - F3 - MSZ 4798:2016 vagy

$\mathrm{C} 40 / 50-\mathrm{AC}_{50}(\mathrm{H})-\mathrm{XC} 4-\mathrm{XF} 4(\mathrm{H})-\mathrm{XK} 3(\mathrm{H})-32$ - bazalt

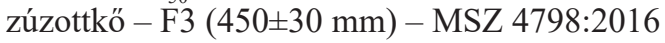

6. példa: Annak a C35/45 nyomószilárdsági osztályú betonnak a jele, amelynek nyomószilárdságát $50 \%$ elfogadási valószínűség mellett értékelték, és amelyből párás, ritkán száraz légterü uszoda vasbeton keretszerkezete készül, névleges legnagyobb szemnagysága $D_{\max }=24 \mathrm{~mm}$ konzisztenciája képlékeny és terülési mértéke 420-480 mm közé esik, tehát konzisztencia osztálya F3, a következő:

C35/45-AC ${ }_{50}(\mathrm{H})$ - XC2 - XD2 - 24 - F3 - MSZ 4798:2016

7. példa: Annak a C25/30 nyomószilárdsági osztályú betonnak a jele, amelyből fagyhatár alatti, talajvízszint feletti vasbeton sávalap készül, vízfelvétele legfeljebb 4 tömeg\%, névleges legnagyobb szemnagysága $D_{\max }=32 \mathrm{~mm}$, konzisztenciája képlékeny és a tervezés idején ismeretes, hogy a konzisztenciát roskadásméréssel fogják meghatározni, és a roskadási mértéknek 50-90 mm közé kell esnie, tehát konzisztencia osztálya S2, a következő:

C25/30 - XC2 - XV0(H) - 32 - S2 - MSZ 4798:2016 és MSZ 4798:2016/2M:2018

8. példa: Annak a C16/20 nyomószilárdsági osztályú betonnak a jele, amelyből káros környezeti hatásnak ki nem tett vasalt beton pincealap készül, névleges legnagyobb szemnagysága $D_{\max }=48 \mathrm{~mm}$, konzisztenciája kissé képlékeny és a tervezés idején ismeretes, hogy a konzisztenciát roskadásméréssel fogják meghatározni és a roskadási mértéknek 1040 mm közé kell esnie, tehát konzisztencia osztálya S1, a következő:

C16/20 - X0v(H) - 48 - S1 - MSZ 4798:2016

9. példa: Annak az LC12/13 nyomószilárdsági osztályú könnyübetonnak a jele, amelynek a testsürüsége szilárd állapotban $1601-1800 \mathrm{~kg} / \mathrm{m}^{3}$ közé esik, adalékanyaga duzzasztott agyagkavics, és amelyből beltéri könnyübeton teherbíró fal épül, névleges legnagyobb szemnagysága $D_{\max }=16 \mathrm{~mm}$, konzisztenciája a kissé képlékeny és a képlékeny határán van, tömörítési mértéke 1,11-1,25 közé esik, konzisztencia osztályának jele a tömörítési mérték jelével kifejezve C2, a következö: LC12/13 - D1,8 - X0b(H) - 16 - duzzasztott agyagkavics C2 - MSZ 4798:2016 vagy

LC12/13 - D1,8 - X0b(H) - 16 - duzzasztott agyagkavics C2 (1,25-1,11) - MSZ 4798:2016

10. példa: Annak a szilárd állapotban 1401-1600 kg/m testsürüségü, LC40/44 nyomószilárdsági osztályú könnyübetonnak a jele, amelynek nyomószilárdságát 50\% elfogadási valószínúség mellett értékelték, légbuborékképző adalékszer nélkül készül, anyaga beépített állapotban váltakozva nedves és száraz, fagy- és jégolvasztósó éri, adalékanyaga duzzasztott agyagkavics, névleges legnagyobb szemnagysága $D_{\max }=8 \mathrm{~mm}$, tömörítési mértéke kisebb, mint 1,04, és amelyből 50 év tervezési élettartamú gyalogoshíd könnyübeton anyagú elöregyártott vasbetonlemeze készül, a következő:

LC40/44-AC ${ }_{50}(\mathrm{H})-\mathrm{D} 1,6-\mathrm{XC} 4-\mathrm{XF} 4(\mathrm{H})-8$ - duzzasztott agyagkavics - C4 - eUT 07.01.21:2016 figyelembevételével - MSZ 4798:2016

vagy

LC40/44-AC ${ }_{50}(\mathrm{H})-\mathrm{D} 1,6-\mathrm{XC} 4-\mathrm{XF} 4(\mathrm{H})-8$ - duzzasztott agyagkavics - C4 $(<1,04)$ - eUT 07.01.21:2016 figyelembevételével - MSZ 4798:2016

Megjegyzések:

- Bár az e-UT 07.01.21:2016 tervezési útmutató 5.2. táblázata értelmében a közlekedésépítési célú, előregyártott könnyübeton tartószerkezeti elemek betonjának nyomószilárdságát mind tervezéskor, mind gyártáskor minden esetben 50\% 
elfogadási valószínüség mellett kell értékelni, célszerü erre a

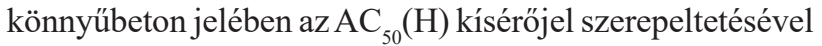
a figyelmet felhívni.

- A könnyübeton fagy- és olvasztósóállóságát többnyire az MSZ CEN/TS 12390-9:2018 müszaki specifikáció szerinti CDF-vizsgálattal, azaz kapilláris vízfelszívásos hámlasztással szokták meghatározni. Az e-UT 07.01.21:2016 tervezési útmutató 6.4.6. szakasza szerint kapilláris felszívásos hámlasztási vizsgálat esetén a könynyübeton akkor tekinthető fagy- és olvasztósóállónak, ha 50 év tervezési élettartam esetén $n=56$ ciklus szám mellett a lehámlott anyag tömege az MSZ 4798:2016 szabvány NAD 9. táblázatának CDF oszlopában szereplö, a környezeti osztálytól függő határértéket nem lépi át. E határérték az XF4(H) környezeti osztályú beton CDF hámlasztási vizsgálati eredményeinek átlagára vonatkozólag $1000 \mathrm{~g} / \mathrm{m}^{2}$, az egyedi értékekre vonatkozólag pedig $1350 \mathrm{~g} / \mathrm{m}^{2}$ lehámlott anyag.

- Mind a peremes hámlasztás, mind a kapilláris felszívásos hámlasztás MSZ 4798:2016 szabvány NAD 7., illetve NAD 9. táblázatában szereplö, $\mathrm{g} / \mathrm{m}^{2}$ mértékegységü hámlási határértéke a térfogategyenlőség elve szerint a kisebb testsürüségü betonra nézve lazább követelmény, mint a nagyobb testsürüségü betonra nézve, hiszen az egységnyi térfogatú könnyebb beton (például könnyübeton) tömege kisebb, mint az egységnyi térfogatú nehezebb beton (például szokványos beton) tömege; tehát a könnyübeton térfogatvesztesége nagyobb, mint a vele egyforma tömegveszteségü szokványos beton térfogatvesztesége. Ha a könnyübeton hámlasztásos fagy-, illetve fagy- és olvasztósóállósági vizsgálatai eredményének értékelése során - az MSZ 4798:2016 szabvány NAD 7. és NAD 9. táblázata szerinti határértékek megtartása mellett - érvényesíteni kívánjuk a térfogategyenlőség elvét, akkor a könnyübetonból lehámlott anyag tömegét a szokványos beton és a könnyübeton tetsürüségének hányadosával át kell számítani a a könnyübetonból lehámlott anyag térfogatával azonos térfogatú szokványos beton tömegére:

$\Delta V_{\text {lehámlott anyag }}=\Delta M_{\text {könnyübeton }} / \rho_{\text {könnyübeton }}=$

$=\Delta M_{\text {szokványos beton }} / \rho_{\text {szokványos beton }}$,

amelyből

$\Delta M_{\text {szokványos beton }}=\left(\rho_{\text {szokványos beton }} / \rho_{\text {könnyübeton }}\right) \times \Delta M_{\text {könnyübeton }}$,

ahol a fagyasztási veszteség térfogategyenlőségi átszámítási tényezője:

$\varphi=\left(\rho_{\text {szokványos beton }} / \rho_{\text {könnyübeton }}\right)$.

Az XF4(H) környezeti osztályú könnyübeton a térfogategyenlőség elve szerint tehát akkor tekinthető fagy- és olvasztósóállónak, ha például a CDF-vizsgálati eredményeinek átlagát tekintve $\varphi \times \Delta M_{\text {könnyübeton, átlag }} \leq 1000$ $\mathrm{g} / \mathrm{m}^{2}$, és az egyes CDF-vizsgálati eredmények tekintetében $\varphi \times \Delta M_{\text {könnyübeton, egyes }} \leq 1350 \mathrm{~g} / \mathrm{m}^{2}$.

A szokványos betonnak a térfogategyenlőségi átszámítási tényezőben szereplő $\rho_{\text {szokványos beton }}$ testsürüsége lehet például a könnyübeton összetételéhez hasonló összetételü szilárd szokványos beton ismert testsürüsége vagy a fagyasztási hámlási veszteség előírt határértékéhez (g/ $\mathrm{m}^{2}$ mértékegységben megadott megengedett legnagyobb értékéhez) rendelt szilárd szokványos referenciabeton (etalon beton) testsürüsége.
A térfogategyenlőség elvét például Németországban a Gera folyó feletti, rudislebeni, mintegy százéves, 1982-ben áradás sújtotta erdei kerékpáros és gyalogos vasbetonhídnak az 1990-es évek végi újjáépítéséhez előregyártott 10 m hosszú és 0,4 m magas vasbeton-áthidalóelem LC40/44 nyomószilárdságú, $1,45 \mathrm{~kg} / \mathrm{m}^{3}$ testsürüségü, $25 \mathrm{~m}^{3}$-nyi könnyübetonjának CDF fagy- és olvasztósóállóság vizsgálata során úgy alkalmazták, hogy az elöírt fagy- és olvasztósóállósági határértéket a $\varphi=2100 / 1600=1,3125$ átszámítási tényezővel elosztották. A nevezőben az $1,45 \mathrm{~kg} / \mathrm{m}^{3}$ testsürüségü könnyübeton D1,6 testsürüségi osztályának felső határértéke, 1600 kg/m³ áll (König et al., 2001), (Faust, 2003).

Megjegyzendő, hogy az újjáépített rudislebeni kerékpáros és gyalogos híd az előregyártott könnyübeton áthidalóelembe beépített, nagyszilárdságú finombetonból készített előfeszített erősítő betonrudakról is nevezetes.

11. példa: Annak az útbetonnak a jele, amelynek formában készített, $150 \times 150 \times 600$ mm méretü, kizsaluzás után véig víz alatt tárolt próbahasábokon meghatározott hajlító-húzószilárdságának karakterisztikus (jellemző) értéke 28 napos korban legalább $4 \mathrm{~N} / \mathrm{mm}^{2}(\mathrm{~F} 4,0)$, a kifúrt magmintából kialakított, $\varnothing 150 \times 150 \mathrm{~mm}$ méretü, vegyesen tárolt próbahengereken meghatározott hasító-húzószilárdságának karakterisztikus (jellemzö) értéke 28 napos korban legalább 2,7 N/mm² (SC2,7), fagy és olvasztósó hatása éri, légbuborékképző adalékszerrel készül és meg kell feleljen a k10/15 kopásállósági osztály követelményének, adalékanyaga $32 \mathrm{~mm}$ legnagyobb szemnagyságú bazalt zúzottkő, friss beton konzisztencia osztálya F2, a következő:

CP4/2,7 - XF4 - XK3(H) - 32 - bazalt zúzottkő - F2 - e-UT 06.03.31:2017 tervezet

Véleményünk szerint a 11. példának megfelelő transzportbeton jele szabatosan a következő:

CP-F4,0 - XF4 - XK3(H) - 32 - bazalt zúzottkő - F2 - e-UT 06.03.31:2017 tervezet

Megjegyzések:

- Az e-UT 06.03.31:2017 útügyi műszaki előírástervezet szerint a pályaburkolati betonok (útpályabetonok) betüjele $\mathrm{CP}$, a betüjel után a sablonban készített, végig víz alatt tárolt, 28 napos korú próbahasábokon meghatározott hajlítóhúzószilárdságának karakterisztikus (jellemző) értékét és törtvonal után a kifúrt magmintákon meghatározottt hasítóhúzószilárdságának karakterisztikus (jellemző) értékét kell feltüntetni, mindkettőt $\mathrm{N} / \mathrm{mm}^{2}$ mértékegységben kifejezve.

- A pályaburkolati betonok jele tartalmazza továbbá az adalékanyag legnagyobb szemnagyságát mm-ben, a friss beton konzisztencia osztályának jelét vagy konzisztenciájának mértékét, az útbeton környezeti osztályának a jelét és az útügyi müszaki előírás számát is.

- Az útpályabetonok szilárdsági osztályának jelével azonban gondjaink vannak, ugyanis a transzportbeton gyártója nem tehető felelőssé a pályalemezbe bedolgozott beton tömörségéért, utókezeléséért, a környezeti hatásoktól is befolyásolt szilárdulási folyamatáért, következésképpen a kifúrt magminta szilárdságáért; a pályaburkolatok szilárdsági jele nincs összhangban a beton jelének felfogásunk szerinti értelmezésével.

- Az MSZ 4798 betonszabvány csak akkor vonatkozik az út- és térburkolatok betonjára, ha az érvényben lévő útügyi müszaki elöírás az MSZ 4798 szabványra hivatkozik.

\section{BETONTERMÉK, BETONGYÁRT- MÁNY}

Cikkünk bevezetésének utolsó mondatában szó esett a betonról, 


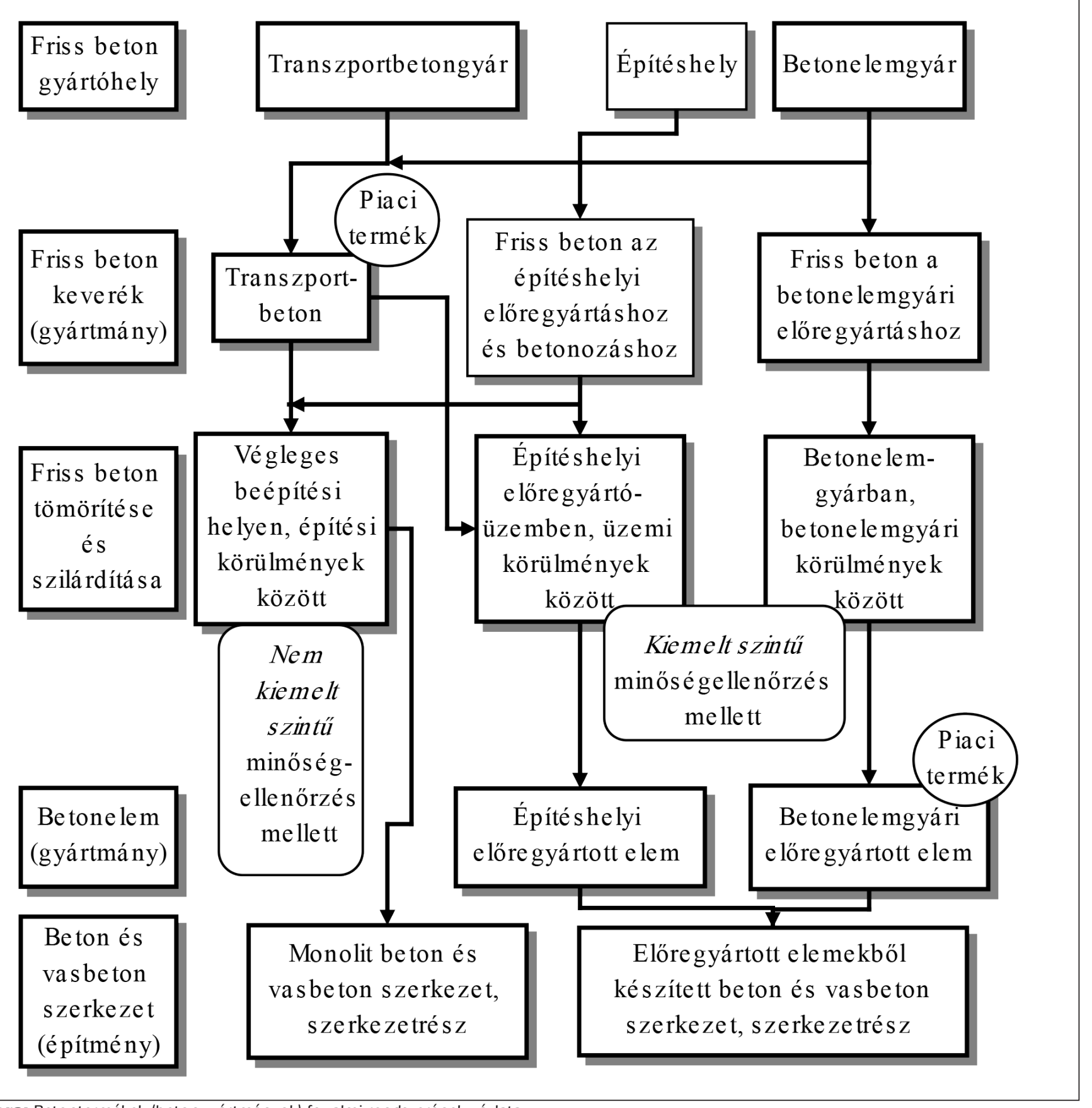

1. ábra: Betontermékek (betongyártmányok) fogalmi rendszerének vázlata

mint termékről, amely fogalmat célszerü külön is elemezni.

Termék: minden ingó dolog - akkor is, ha utóbb más ingó vagy ingatlan alkotórészévé vált - valamint a villamos energia (1993. évi X. tv. 1. § (1) bek.).

A 3/2003. (I. 25.) BM-GKM-KvVM együttes rendelet 2. § 1. pontja szerint építési termék minden olyan anyag, szerkezet, berendezés vagy több, különböző részből összeállított elem, amelyet azért állítanak elő, hogy építménybe állandó jelleggel beépítsék.

Cikkünkben a ,betontermék” kifejezést a „,betongyártmány" szinonimájaként értelmezzük, beleértve a félkészbetonterméket is, függetlenül az előállítás közvetlen céljától és a hasznosulás módjától.

A beton-építőanyagipar alapvetően kétféle betonterméket állít elő: friss beton keverékeket és megszilárdult beton-, vasbeton- és feszített vasbetonelemeket. Az ezek felhasználásával monolitbetonból és/vagy elöregyártott elemekből készített beton, vasbeton, feszített vasbeton szerkezetek építése nem a beton-építőanyagipar, hanem az építőipar tevékenységi körébe tartozik (1. ábra).
Friss betont a transzportbetongyárakban, a betonelemgyárakban és az esetleg építéshelyen müködtetett betonüzemekben állítanak elő. A transzportbetonból általában monolit beton és beton-, vasbetonszerkezetek készülnek, de a transzportbeton az építéshelyen elöregyártott vasbetonszerkezeti elemeknek is alkotóanyaga lehet. A betonelemgyárak a friss beton keverékből elsősorban előregyártott beton-, vasbeton- és feszített vasbetonelemet gyártanak, de a friss betont akár transzportbetonként is hasznosítják. Az építéshelyen a szükségböl odatelepített elöregyártóüzem kiszolgálására olykor betonkeverö-üzemet létesítenek, de nem kizárt, hogy az építéshelyen kevert friss betonból monolit beton- vagy vasbetonszerkezetrész is készül.

A beton, vasbeton-, feszített vasbetonelemek elöregyártásához a betonelemgyárban vagy az építéshelyen kevert friss beton a betonkeverés telephelyét el nem hagyván, nem transzportbeton.

A friss betonból általában monolit beton, vasbeton vagy elöregyártott beton, vasbeton-, feszített vasbetonelem készül. A monolit betonok és az elöregyártottelemek tömörítése, il- 
letve tömörítettsége közé általában nem tehető egyenlőségjel. A monolit szerkezetek betonja végleges beépítési helyén, az ott uralkodó építési (külön védelem híján általában az időjárási) körülmények között; az előregyártott elemek betonja a betonelemgyári vagy az építéshelyi elöregyártó-üzem szabályozott körülményei között szilárdul.

A betongyártás teljes folyamatát tekintve úgy véljük, hogy a betonelemgyárakban és az építéshelyi előregyártó-üzemekben könnyebb kiemelt szintű minőségellenőrzést végezni, mint a monolit szerkezetek készítése esetén, ezért ezt a különbséget tekintjük a vasbetonszerkezetek - betonfedés szempontjából fontos - szerkezeti osztályba sorolása egyik feltételének.

Ismert, hogy a friss betonból, sablonban készülő vizsgálati próbatesteket az MSZ 4798:2016 szabvány szerint szabályozott laboratóriumi körülmények között kell tömöríteni és utókezelni, amely körülmények mindenképpen eltérnek a monolit betonok és az elöregyártott betonok tömörítési és szilárdulási körülményeitől, beleértve a megépült monolit vagy előregyártott szerkezetekből kifúrt vagy kivágott minták tömörítési és szilárdulási körülményeit is.

A transzportbetont és a betonelemgyári beton-, vasbeton- és feszített vasbetonelemeket piaci áruforgalomban értékesítik, ezért ezeket piaci termékeknek nevezzük.

A betonelemgyártási célra előállított friss betont, az építéshelyen helyszíni beépítés vagy elöregyártás céljából készített friss betont, a helyszíni elöregyártással készült előregyártott elemeket nem hozzák piaci áruforgalomba, ezért ezeket, bár termékek, nem tekintjük piaci termékeknek (adás-vétel tárgyát képező árunak).

A müszaki szabályozásban ezzel szemben termék, illetve betontermék alatt általában piaci áruforgalomba kerülö vagy került betonterméket értenek. Ez azért zavaró, mert a termékszabványok nem csak ezekre, hanem a piaci értékesítésre nem szánt, a gyártó maga végezte további feldolgozás céljából előállított gyártmányokra (termékekre) is vonatkoznak. Ilyen például a betonelemgyárban kevert friss beton, amelyből a betonelemgyárban elöregyártott betonelemek készülnek, és amelyre ugyanaz a betontermékszabvány érvényes, mint a piaci terméket képviselö transzportbetonra (MSZ EN 206:2013+A1:2017, illetve MSZ 4798:2016, MSZ 4798:2016/2M:2018). Ennek folyománya lehet, hogy az előregyártott elemek MSZ EN 13369:2013 termékszabványa a felhasználható friss betonok között azok kereskedelmi megítélése alapján nem tesz különbséget.

A betongyártmányok (betontermékek) fogalmi rendszerét bemutató 1. ábra első oszlopában zárójel használatával érzékeltetjük, hogy termék alatt a gyártósorról lekerülő gyártmányt értjük, felhasználásától függetlenül, tehát akár piaci termék, akár nem.

Érdemes emlékezetünkbe idézni a visszavont MI-04562:1992 építésügyi ágazati műszaki irányelvben szereplő, e fejezet fogalomköréhez tartozó fontosabb meghatározásokat is:

- Transzportbeton: az MI-04-562:1992 építésügyi ágazati müszaki irányelv szerint készített friss betonkeverék, amelynek alapanyagait a transzportbeton-üzemben mérik ki, telepített vagy mobil keveröberendezésben keverik, szállítóeszközben szállítják és a vevő felelős képviselőjének készre kevert állapotban adják át.

- A betonkeverö-üzem akkor is transzportbeton-üzemnek minősül, ha betonját nem adja el betonáruként, hanem vállalata építéshelyére szállítja.

- Ha egy vállalaton belül más termelési egység keveri meg a betont, mint amelyik bedolgozza, akkor a szerkezetet (mütárgyat) készítő szervezet (építésvezetőség) a megrendelö (vevö).
- Az MI-04-562:1992 építésügyi ágazati müszaki irányelv szerint a betonkeverék átvételét követő tevékenység a vevő érdekkörébe tartozik, ezért ennek megfelelöen végrehajtása nem a szállító felelössége.

Az MI-04-562:1992 építésügyi ágazati müszaki irányelvben a fentieken kívül részletesen foglalkoztak a transzportbeton-üzemekkel és azok vezetésével, az üzemi berendezésekkel, a szállítóeszközökkel és a szállítással, a beton alapanyagaival, azok átvételével, továbbá a friss és a megszilárdult betonnal, a betonösszetétellel, valamint a beton készítésével szemben támasztott követelményekkel, a beton megrendelésével és szállításával, a beton átadásával és átvételével, a beton minőségének és az üzemi berendezések ellenőrzésével, a minőség tanúsításával és az adatok nyilvántartásával.

\section{A KIINDULÁSI ÉS A FOLYÓSÍTÓ- SZERES BETON, ELTARTHATÓ- SÁGI IDŐ}

Ha a beton szabványos jele szerinti, folyósító adalékszer nélküli beton konzisztenciája földnedvesebb (szárazabb) az elvárt építéshelyi bedolgozási konzisztenciánál, akkor a betonhoz folyósító adalékszert kell keverni. Az ilyen folyósító adalékszer nélkül készülő, és képlékenyítésre, folyósításra nem feltétlenül alkalmas összetételü friss betont kiindulási betonnak nevezzük.

Grübl et al. (2001) szerint a kiindulási beton konzisztenciája általában a földnedvestől a kissé képlékenyig terjed, MSZ 4798:2016 szabvány szerinti terülési mértéke 410 mmnél kisebb (F1, F2), tömörítési mértéke 1,11-nál nagyobb $(\mathrm{C} 0$, $\mathrm{C} 1, \mathrm{C} 2$ ). A pályabetonok készítéséhez alkalmazott kiindulási betonok terülési mértéke 250-330 mm (F1), tömörítési mértéke 1,2-1,4 (C1-C2).

Bonzel et al. (1973) arról írtak, hogy a folyósításra alkalmas kiindulási beton terülési mértéke legalább 380 mm legyen, mert ez alá csökkenő terülési mérték esetén a folyósító adalékszerek hatékonysága jelentősen romlik, és a 320 mm-nél kisebb terülési mértékű kiindulási beton adalékszerrel gyakorlatilag már nem folyósítható. Ugyanakkor 440 mm-nél nagyobb terülési mértékü kiindulási betonból sem lehet jó összetartóképességü folyósítószeres betont készíteni. Ezt a véleményt tükrözi Wesche (1993) ábrája is, amelynek hátterében Kern et al. (1976) közleménye áll (2. ábra).

A kiindulási beton ne legyen se túl durvaszemü, se túl finomszemü. A „B” határgörbe alatt, vagy akár egy kissé afölött futó szemmegoszlási görbe a kedvező, ha a finomszemek tartományában számottevően a „B” határgörbe felett helyezkedik el. A homokos kavics adalékanyag szemalakjánál fogva előnyösebb, mint a zúzottkő. Az acélszerelésen való átfolyás elősegítése érdekében az adalékanyag legnagyobb szemnagysága kisebb, szemmegoszlása finomszemekben gazdagabbbb legyen, mint az egyébként alkalmazott földnedves betonoké. Például $32 \mathrm{~mm}$ legnagyobb szemnagyságú kiindulási beton esetén a legfeljebb 0,25 mm szemnagyságú finomrésztartalom 360-420 $\mathrm{kg} / \mathrm{m}^{3}$ közé essék, amelyből a cementtartalom 300-350 kg/m³ legyen (Bonzel et al., 1973), (Grübl et al., 2001).

A kiindulási friss betont a folyósító adalékszer hatásának érvényesüléséhez olykor lágyítani szükséges, hogy annak konzisztenciája, illetve az ahhoz tartozó víz- és cementtartalom elérje a képlékenyítéshez, folyósításhoz szükséges mértéket.

A folyósítható konzisztencia beállításához célszerü figyelembe venni, hogy valamely betonkeverék vízigénye az adalékanyag és a cement vízigényéből becsülhető meg. Grübl et al. (2001) könyvében olvashatjuk, hogy Koch et al. (1971) 


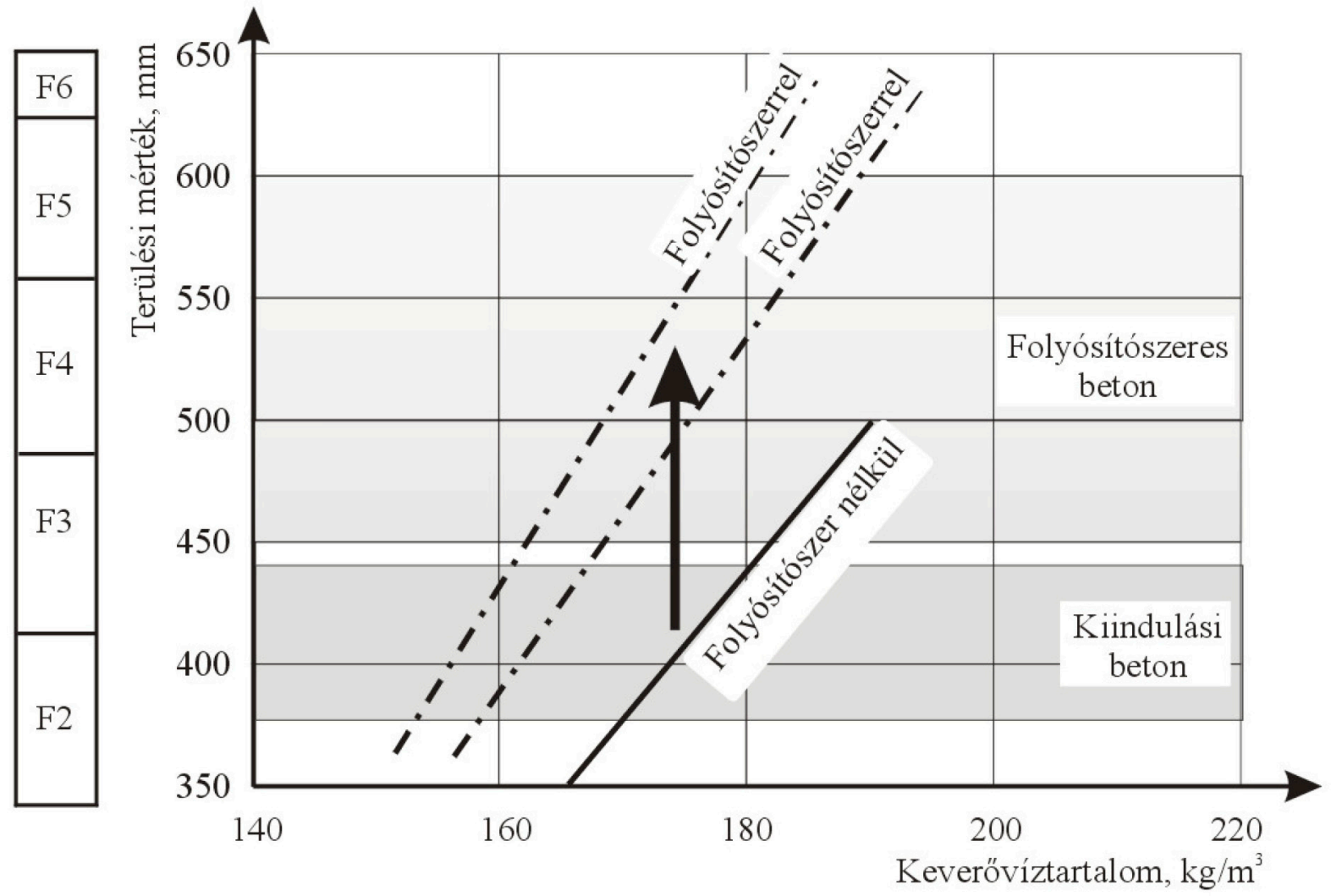

szerint a cement vízigénye általában $85-100 \mathrm{~kg} /\left(\right.$ cement $\left.\mathrm{m}^{3}\right)$.

A közepes őrlésfinomságú cementek (fajlagos felületük $2800-4000 \mathrm{~cm}^{2} / \mathrm{g}$ ) a friss beton tulajdonságait, különösen a beton bedolgozhatóságát gyakorlatilag nem befolyásolják; az ennél durvábbra örölt cementek (fajlagos felületük kisebb mint $2800 \mathrm{~cm}^{2} / \mathrm{g}$ ) vízigénye kisebb, a finomabbra örölt cementek (fajlagos felületük nagyobb mint $4000 \mathrm{~cm}^{2} / \mathrm{g}$ ) vízigénye nagyobb, a nagyon finomra örölt cementek (fajlagos felületük $5000-7000 \mathrm{~cm}^{2} / \mathrm{g}$ ) emellett nagy cementtartalom esetén a beton bedolgozhatóságát is megnehezítik. A porszerü anyagok (például fémoxid betonszínezőanyag) sürünfolyóssá, ragadóssá teszik a friss betont és növelik a vízigényét. Az adalékanyagok szemmegoszlásának javítása a finomszemtartalom növelésével a jobb térkitöltés érdekében akár csökkentheti is az azonos konzisztenciájú friss beton vízigényét (Müller et al., 2009).

A szemmegoszlási határgörbéknek megfelelö szemmegoszlású homokos kavics adalékanyaggal készített, adalékszer nélküli friss beton Springenschmid (2007) szerinti hozzávetőleges vízigénye az 1. táblázatban látható. Ettől némileg eltérő hozzávetőleges vízigény értékek $(w)$ találhatók a szemmegoszlási határgörbék esetére a Zement-Merkblatt B 20, (2017) müszaki útmutató 3. táblázatában, amelyeket - a német $k$-érték (Körnungsziffer) és az MSZ 4798:2016 szabvány szerinti $m$ finomsági modulus közelítő (mert a német és a magyar határgörbék nem pontosan fedik egymást) átszámításával $(k \approx m-2)$ az adalékanyag finomsági modulusa $(m)$ függvényében - a következő tapasztalati összefüggésekkel írhatunk fel:

- földnedves konzisztencia esetén: $w=1100 /(k+3)=$ $100 /(m+1)$

- kissé képlékeny konzisztencia esetén: $w=1200 /(k+3)$ $=1200 /(m+1)$

- képlékeny konzisztenia esetén: $w=1300 /(k+3)=$ $1300 /(m+1)$

Röhling et al. (2012) - hivatkozással a DBV Deutscher Beton-Verein (1995) kézikönyvére - grafikusan lényegében
Springenschmid (2007) és a Zement-Merkblatt B 20 (2017) vízigény adatait jelenítették meg (3. ábra). Grübl et al. (2001) könyvében hasonló ábrák találhatók azzal a különbséggel, hogy a független változó a tömörítési mérték vagy az adalékanyag finomsági modulusa, a függő változó pedig mindig a friss beton vízigénye. Grübl et al. (2001) forrásként Bonzel et al. (1978) munkáját jelölte meg.

A zúzottkő betonok vízigénye $8 \mathrm{~mm}$ feletti szemnagyságú zúzottkő esetén mintegy 5\%-kal, 4 mm feletti szemnagyságú zúzottkő esetén mintegy 10\%-kal nagyobb a homokos kavics adalékanyagú beton vízigényénél. Ha a betonban a lisztfinomságú szemek (az összes legfeljebb 0,125 mm szemnagyságú beton alkotórész) mennyisége $350 \mathrm{~kg} / \mathrm{m}^{3}$-nél több, akkor $10 \mathrm{~kg} / \mathrm{m}^{3}$ lisztfinomságú szemtartalmanként a vízigény további $1,0 \mathrm{~kg} / \mathrm{m}^{3}$-rel megnövekszik. Légbuborékképző adalékszer alkalmazása esetén a keverővíz adagolást $1,5 \%$ légbuboréktérfogat határérték felett minden $1 \%$ légbuboréktérfogat után mintegy $5 \mathrm{~kg} / \mathrm{m}^{3}$-rel csökkenteni lehet (Röhling et al., 2012).

Ujhelyi (2005) kísérleti alapon módszert dolgozott ki a betonkeverék vízigényének meghatározására, és a vízigényt a változatlan konzisztenciához (víztartóképességhez) tartozó cementtartalommal fejezte ki. Könyvének 4.2. fejezetében számpéldákon mutatta be a betonkeverék vízigényének számítását és a kiszámított vízigénynek megfelelö betonösszetétel meghatározását.

Az MSZ 4798:2016 és MSZ 4798:2016/2M:2018 szabvány szerinti környezeti osztályokhoz tartozó kiindulási betonok víztartalmát (keverővíztartalmát) a megengedett legnagyobb víz-cement tényező és a megkövetelt legkisebb cementtartalom értékének összeszorzásával a 2. táblázatban számítottuk ki $\left(v_{0}=x_{\max } \times c_{\text {min }}\right)$, de ez a víztartalom olykor kevés a friss beton építéshelyi bedolgozhatóságához és a folyósító adalékszer hatékony múködéséhez.

Ilyenkor az adalékszer nélküli kiindulási betont a megkövetelt legkisebb cementtartalom $\left(c_{\text {min }}\right)$ és a megengedett legna- 
1. táblázat: A homokos kavics adalékanyaggal, adalékszer nélkül készített friss beton hozzávetőleges vízigénye Springenschmid (2007) szerint, $\mathrm{kg} /\left(\right.$ betömörített friss beton $\mathrm{m}^{3}$ )

\begin{tabular}{|c|c|c|c|c|c|c|c|c|c|}
\hline \multirow{6}{*}{ Adalékanyag vízigénye } & \multicolumn{9}{|c|}{$D_{\max }$, Adalékanyag legnagyobb szemnagysága, mm } \\
\hline & \multicolumn{3}{|c|}{8} & & \multicolumn{2}{|l|}{16} & \multicolumn{3}{|c|}{32} \\
\hline & \multicolumn{9}{|c|}{ Szemmegoszlási határgörbe } \\
\hline & A8 & B8 & $\mathrm{C} 8$ & A16 & $\mathrm{B} 16$ & $\mathrm{C} 16$ & A32 & B32 & $\mathrm{C} 32$ \\
\hline & \multicolumn{9}{|c|}{ Szemmegoszlási határgörbék $m$ finomsági modulusa } \\
\hline & 5,70 & 4,90 & 4,30 & 6,60 & 5,60 & 4,80 & 7,55 & 6,35 & 5,40 \\
\hline Kicsi & 150 & 170 & 185 & 120 & 140 & 175 & 105 & 130 & 160 \\
\hline Nagy & 155 & 175 & 195 & 140 & 150 & 185 & 130 & 140 & 165 \\
\hline & \multicolumn{9}{|c|}{ Kissé képlékeny konzisztencia, jele: S1, F2, C2 } \\
\hline Kicsi & 180 & 195 & 210 & 150 & 175 & 200 & 130 & 160 & 190 \\
\hline Nagy & 185 & 200 & 225 & 165 & 180 & 210 & 155 & 170 & 195 \\
\hline & \multicolumn{9}{|c|}{ Képlékeny konzisztencia, jele: S2, F3, C3 } \\
\hline Nagy & 210 & 225 & 250 & 190 & 205 & 235 & 170 & 195 & 220 \\
\hline
\end{tabular}

gyobb víztartalom összetartozó, arányos növelésével lehet - a megengedett legnagyobb víz-cement tényező $\left(x_{\max }\right)$ megtartása mellett - lágyítani úgy, hogy a kiindulási beton konzisztenciája a folyósításhoz szükséges konzisztencia-tartományba kerüljön. A folyósításhoz szükséges konzisztenciájúvá tett kiindulási beton víztartalma eléri a képlékenyítéshez, folyósításhoz szükséges vízigényt (4. ábra). Például:

- az XF3(H) környezeti osztályú kiindulási betont 340 kg/ $\mathrm{m}^{3}$ cementtartalom helyett $355 \mathrm{~kg} / \mathrm{m}^{3}$ cementtartalommal kell elkészíteni ahhoz, hogy a víztartalma $0,45 \times 355=$ $159,7 \mathrm{~kg} / \mathrm{m}^{3}$ legyen,

- az XF4(H) környezeti osztályú kiindulási betont 360 kg/ $\mathrm{m}^{3}$ cementtartalom helyett $400 \mathrm{~kg} / \mathrm{m}^{3}$ cementtartalommal kell elkészíteni ahhoz, hogy a víztartalma $0,4 \times 400=$ $160,0 \mathrm{~kg} / \mathrm{m}^{3}$ legyen.

Az MSZ 4798:2016 szabvány szerinti $135 \mathrm{~kg} / \mathrm{m}^{3}$ értékü alsó víztartalom érték, mint az egyik szélső eset, $55 \mathrm{~kg} / \mathrm{m}^{3}$ cementtöbblettel $0,45 \times 355=159,7 \mathrm{~kg} / \mathrm{m}^{3}$ értékre emelhető (XV3(H) környezeti osztály).

Az MSZ 4798:2016/2M:2018 szabvány szerinti 138 kg/ $\mathrm{m}^{3}$ értékü alsó víztartalom érték, mint a másik szélső eset, 55 $\mathrm{kg} / \mathrm{m}^{3}$ hatékony kötőanyagtöbblettel $0,4 \times 400=160,0 \mathrm{~kg} / \mathrm{m}^{3}$ értékre emelhető (XA6(H) környezeti osztály). Ez utóbbi 400 $\mathrm{kg} / \mathrm{m}^{3}$ hatékony kötőanyagtartalom az XA6(H) környezeti osztályban megkövetelt hatékony kötőanyagtartalom $\left(345 \mathrm{~kg} / \mathrm{m}^{3}\right)$ 116\%-a, ami nagyobb annál, mint amennyit a portlandittartalom

3. ábra: A homokos kavics adalékanyaggal készített friss beton hozzávetőleges vízigénye Röhling et al. (2012) szerint, a szemmegoszlási határgörbék finomsági modulusa helyének bejelölésével

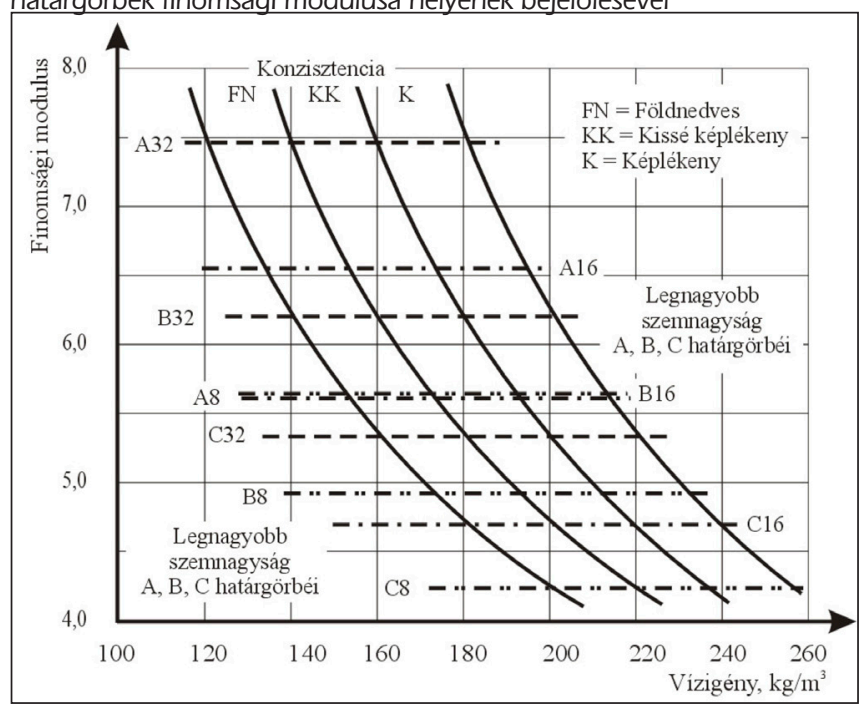

$\left(\mathrm{Ca}(\mathrm{OH})_{2}\right.$-tartalom) korlátozása, illetve a beton savállósága érdekében az MSZ 4798:2016/2M:2018 szabványban megengednek (105\%). Ha azonban azt akarjuk, hogy a kiindulási beton víztartalma $160 \mathrm{~kg} / \mathrm{m}^{3}$ lehessen, akkor meg kell engedni, hogy a legnagyobb hatékony kötőanyagtartalom az XA4(H), XA5(H) és XA6(H) környezeti osztályban a legkisebb hatékony kötőanyagtartalomnak 105\%-a helyett rendre a 112\%-a (358 $\left.\mathrm{kg} / \mathrm{m}^{3}\right), 114 \%$-a $\left(376 \mathrm{~kg} / \mathrm{m}^{3}\right)$ és $116 \%$-a $\left(400 \mathrm{~kg} / \mathrm{m}^{3}\right)$ lehessen.

A folyósító adalékszeres beton folyós vagy képlékeny konzisztenciájú legyen, hogy a zsaluzatba jól be lehessen dolgozni (Kausay, 2006/4):

Folyós betonból igen sürün vasalt, karcsú, nehezen hozzáférhető szerkezetek is készíthetőek. Gyakran víz alatti betonozáshoz alkalmazzák. Folyós betont csak folyósító adalékszerrel szabad készíteni. Mintegy 20 \% esésű csőben vagy lejtőn magától folyik, és ürítéskor nagyon lapos kúpot képez. Tömöríteni alig, vagy nem szükséges. Az F5 konzisztencia osztályú betonból készített vékony lemezeket általában különösebb tömörítés nélkül el lehet készíteni, mert a még meglévö nagyobb pórusok a beton felület lehúzása során megszünnek. Ha a konzisztencia az F4 osztályba tartozik, akkor célszerü a betont vibrópallóval tömöríteni. Pillérek, falak, magas gerendák készítésekor a folyós betont alulról felfelé haladva könnyedén vibrálni kell, és nem például vasrúddal szurkálni. A folyós beton elönye, hogy könnyen szivattyúzható, nehéz körülmények között is gyorsan beépíthető. Hátránya, hogy a folyós beton összetételét igen gondosan kell megtervezni és betartani. Zsugorodása jelentős. A nagyon képlékeny vagy kissé folyós beton (Németországban „Sehr weicher Beton”) konzisztencia osztálya például F4, a folyós betoné (Németországban „Fließfähiger Beton”) F5.

A képlékeny betont sürün vasalt szerkezetek készítéséhez lehet használni. Gyenge vibrálással is tömöríthetö. Felhasználásával nagy kiterjedésű szerkezetek, mechanikai igénybevételeknek kitett betonok, látszóbetonok is készíthetőek. Előnye a szivattyúzhatóság, a könnyü bedolgozhatóság. Jól vibrálható. Hátránya a nagy cementigény, a szétosztályozódási, zsugorodási, kivérzési hajlam. Ma a betonok mintegy 80 \%-a ezzel a konzisztenciával készül. A képlékeny beton konzisztencia osztálya például F3. Németországban ezt a konzisztenciát régebben KR jelü „,Regelkonsistenz”-nek nevezték, ma az F3 terülési osztályú betont németül „Weicher Beton”-nak hívják.

A folyósító adalékszer hatása az eltarthatósági idő múltával lecseng. Az adalékszer folyósító hatásának megszüntével, az eltarthatósági idő múltával a folyósítószeres beton konzisztenciája lényegében meg kell feleljen a kiindulási beton 
2. táblázat: Az MSZ 4798:2016 és MSZ 4798:2016/2M:2018 szabvány szerinti környezeti osztályokhoz tartozó kiindulási betonok víztartalma (keverővíztartalma)

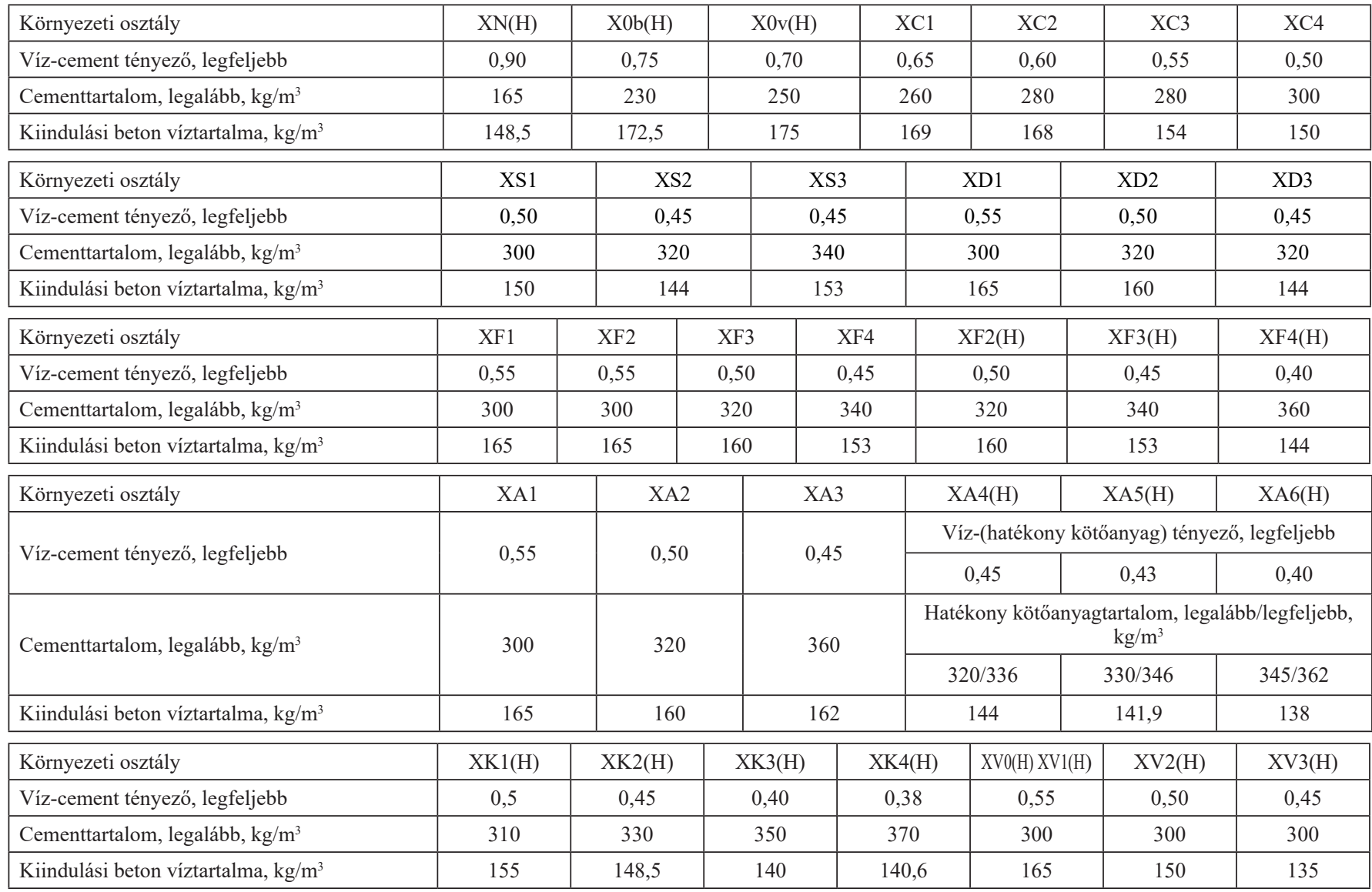

konzisztenciájának, testsürüségének és a megszilárdult beton tulajdonságainak. A folyósítószeres betonnak a megszilárdult betonra vonatkozó követelményeket folyósító adalékszer nélkül is ki kell elégítenie (Bonzel et al., 1973, Grübl et al., 2001).

A folyósítószeres friss betont az eltarthatósági időtartamon belül be kell dolgozni (5. ábra). Messzire szállított transzportbeton esetén a folyósítószert röviddel a bedolgozás előtt célszerü a mixer-gépkocsiban a kiindulási betonhoz keverni, a keverési idő legalább 3 perc legyen (Bonzel et al. 1973). A friss beton eltarthatósági időtartamát, illetve kellő bedolgozhatóságát külső körülményként a környezeti feltételek, mint például a hőmérséklet, a páratartalom, belső körülményként a beton hömérséklete és összetétele, mint például a cementfajta, a cementtartalom, a víz-cement tényező, az adalékszerhatás

4. ábra: A kiindulási beton konzisztenciájának lágyítása a megkövetelt legkisebb cementtartalomnak megfelelő kiindulási cementtartalom (c $c_{\text {min }}$ ( növelésével, a megengedett legnagyobb víz-cement tényező $\left(x_{\max }\right)$ megtartása mellett, a kiindulási beton adalékszeres folyósíthatósága érdekében. Elvi vázlat

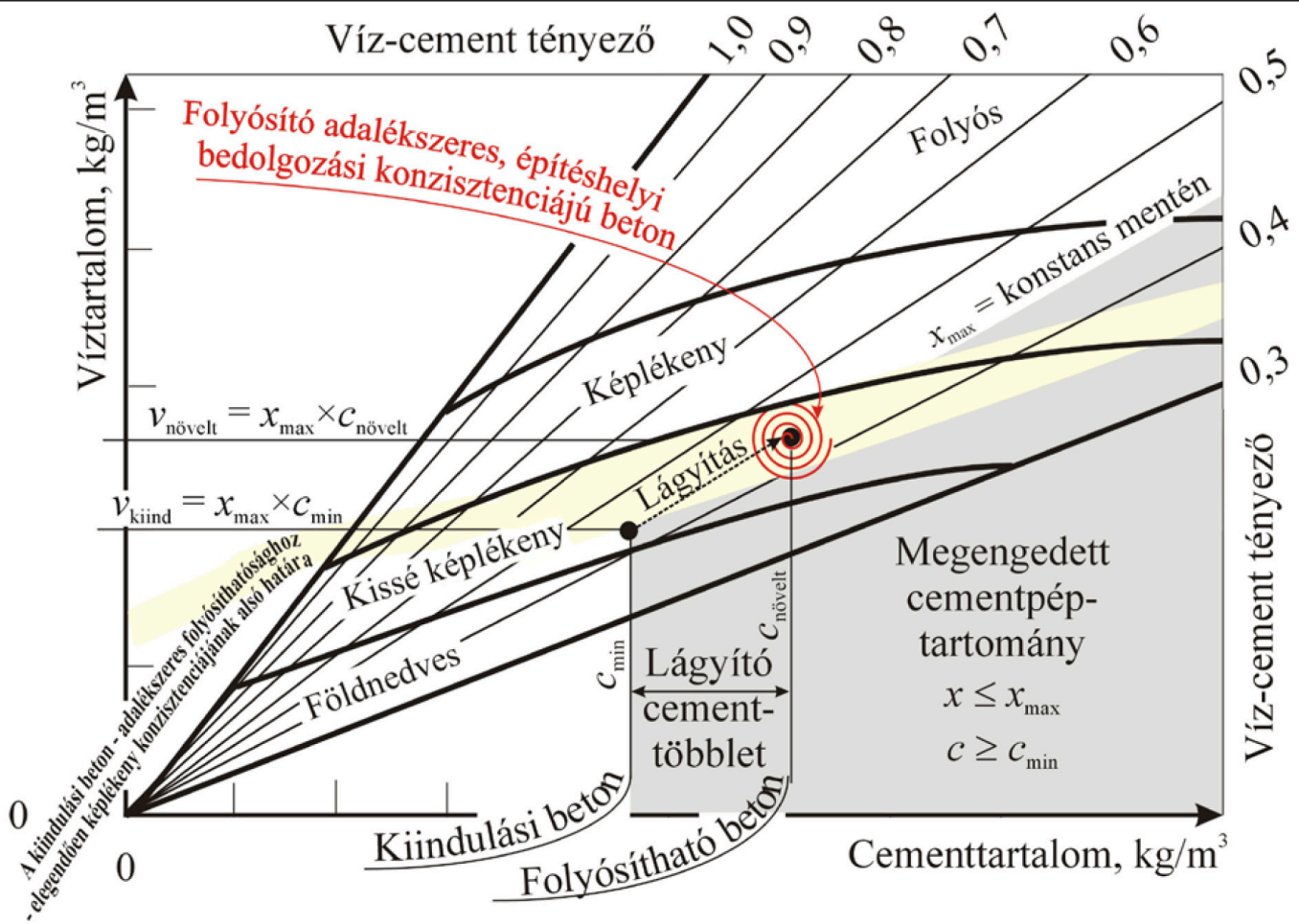




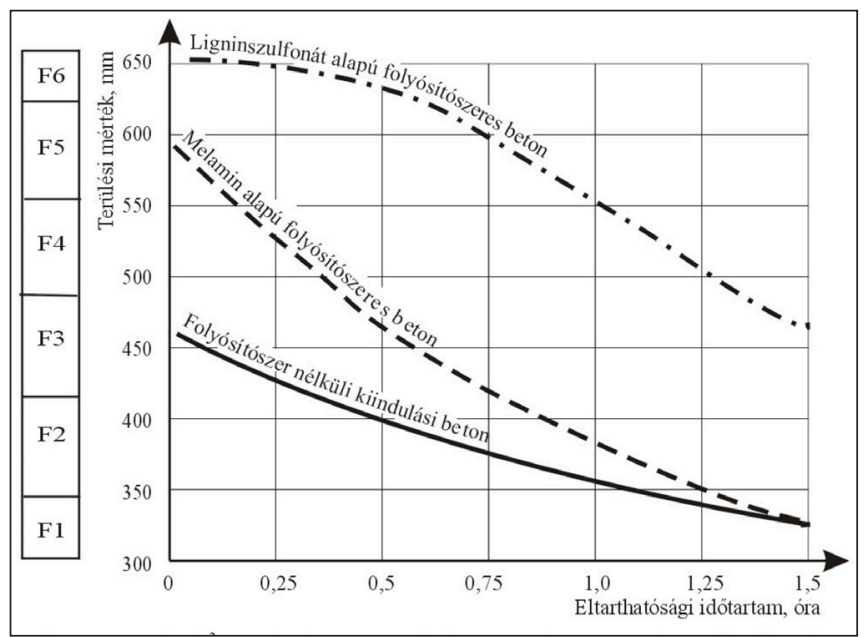

5. ábra: $320 \mathrm{~kg} / \mathrm{m3}$ portlandcement-tartalmú, 0,56 víz-cement tényezőjü friss beton eltarthatósági időtartama $20{ }^{\circ} \mathrm{C}$ hőmérsékleten Wesche (1993) és Kern et al. (1976) után

befolyásolja (Wierig et al., 1989, 1990, 1998).

A friss beton eltarthatóságát a gyakorlatban a betonöszszetétel és a hőmérséklet függvényében a konzisztencia-, a testsürüség- és a nyomószilárdság-változás függvényeként szokás kifejezni.

Az MSZ 4798:2016 szabvány 7.7. szakasza szerint a friss beton eltarthatósága az az időtartam, amely alatt a betonkeverék a víz hozzáadásától számítva a bedolgozhatóságából csak annyit veszít, hogy az adott körülmények (hőmérséklet, vízcement tényező, cementtípus, szállítási távolság stb.) között még kellö tömörségüre bedolgozható, azaz nem kezdődött meg sem a beton merevedése, sem a cement kötése.

A MÉASZ ME-04.19:1995 müszaki elöírás 4. fejezetének 4.2.1.3. szakaszában olvashatjuk, hogy a friss betont általában azon időtartamon át lehet eltarthatónak tekinteni, amely alatt - a friss betonkeverék konzisztenciája legfeljebb egy konzisztencia osztállyal,

- a betömörített beton testsürüsége legfeljebb $30 \mathrm{~kg} / \mathrm{m}^{3}$-rel,

- a 28 napos korú betonpróbatestek nyomószilárdsága legfeljebb 10\%-kal csökken a keverés után azonnal vett minták vizsgálati eredményeihez képest.

Az eltarthatóság vizsgálatához az adott összetételü, adott hőmérsékleten megkevert betonkeverékből azonnal, majd tartályba helyezése és légmentes lefedés után 20 percenként kell olyan mennyiségű mintát kivenni, amelyből a konzisztencia vizsgálata elvégezhető, és legalább 3 darab nyomószilárdság-vizsgálati próbatest készíthető. A konzisztenciát a beton megkeverése után, majd 20 percenként; az azonnali és 20 percenkénti mintavételekhez tartozó nyomószilárdságot és testsürüséget a beton 28 napos korában kell megvizsgálni. A vizsgálatokat minden esetben az MSZ 4798:2016 szabványban leírtaknak megfelelően kell végezni, és a vizsgálati eredményeket jegyzőkönyvben fel kell jegyezni.

A visszavont MI-04-562:1992 építésügyi ágazati müszaki irányelv 2. táblázata szerint a transzportbeton szállítási időtartama a 3. táblázat szerinti lehet. Adott hőmérsékleten a lágyabb beton hosszabb ideig, illetve messzebbre szállítható. A megengedett szállítási időtartamon belül érkezett szállító gépkocsiból a friss betont félórán belül ki kell üríteni, és be kell dolgozni.
3. táblázat: Transzportbeton megengedett szállítási időtartama a visszavont MI-04-562:1992 építésügyi ágazati müszaki irányelv 2. táblázata szerint

\begin{tabular}{|c|c|c|}
\hline $\begin{array}{c}\text { Szállítási időtartam } \\
\text { legfeljebb, perc }\end{array}$ & Konzisztencia & $\begin{array}{c}\text { Hömérséklet } \\
{ }^{\circ} \mathrm{C}\end{array}$ \\
\hline 30 & $\begin{array}{c}\text { Földnedves - } \\
\text { Kissé képlékeny }\end{array}$ & $20-30$ \\
\hline 45 & $\begin{array}{c}\text { Földnedves - } \\
\text { Kissé képlékeny }\end{array}$ & $5-19$ \\
\hline 60 & $\begin{array}{c}\text { Kissé képlékeny - } \\
\text { Folyós }\end{array}$ & $20-30$ \\
\hline 90 & $\begin{array}{c}\text { Kissé képlékeny - } \\
\text { Folyós }\end{array}$ & $5-19$ \\
\hline
\end{tabular}

\section{VÁZLATOS BETONTECHNO- LÓGIAI MUNKAMENETTERV AZ ÉPÍTÉSHELYI BEDOLGOZÁSI KONZISZTENCIA BIZTOSÍTÁSÁ- $\mathrm{HOZ}$}

Feltétel: A beton nyomószilárdsági osztályát

- az MSZ EN 1992-1-1:2010, MSZ EN 1992-2:2009

(Eurocode 2) szerint,

- vagy megegyezés esetén az MSZ 4798:2016 szabvány „P” melléklete,

- megegyezés hiányában az MSZ 4798:2016 szabvány „O” mellékleteszerint kell meghatározni. Ugyanígy kell ellenőrizni a beépítésre kerülő beton minőségét nyomószilárdság szerint, és mindig az MSZ 4798:2016 szabványban leírt módon.

Az Eurocode 2 szabványtól eltérő nyomószilárdsági osztály, illetve karakterisztikus (jellemző) érték meghatározásának értelmezéséhez ki kell(ene) kérni a statikus tervező hozzájárulását.

1. Szerkezeti osztályba sorolás

A létesítendő mütárgy beton-, vasbeton- és feszített vasbeton szerkezeti elemeit szerkezeti osztályba kell sorolni az MSZ EN 1992-1-1:2010 szabvány 4.4.1.2. szakasza szerint.

Eredmény: Az adott szerkezeti osztályú, adott tervezési élettartamú, adott környezeti osztályú és adott nyomószilárdsági osztályú betonok jegyzéke (listája) a következő adatokat tratalmazza:

- nyomószilárdsági osztály $\left(\mathrm{C} \ldots / . .\right.$. vagy $\mathrm{C} \ldots / . . .-\mathrm{AC}_{50}(\mathrm{H})$, illetve LC.../... vagy LC.../...-AC s0 $_{50}(\mathrm{H})$,

- környezeti osztály,

- legnagyobb szemnagyság,

- tervezési élettartam,

- szabványjelzete(MSZ4798:2016,MSZ4798:2016/2M:2018)

- beton mennyisége.

2. Az ajánlatkérés elsö lépése

Az 1. alatti adatokkal a különböző betonfajtákra (1. alatti jegyzékenkénti betonokra) ajánlatot kell kérni betongyártóktól.

Feltétel: Az ajánlott beton összetétele folyósitó adalékszer nélkül kell megfeleljen a környezeti osztályban elöírt betonösszetételnek, valamint az erőtani számítás és a környezeti osztály feltétele szerinti mértékadó nyomószilárdsági osztálynak, tehát az ajánlatkérés első lépése a „kiindulási betonra" vonatkozik.

A gyártónak a kiindulási betonra vonatkozó ajánlatában szerepelnie kell a típusvizsgálat végeredményét tartalmazó jegyzőkönyvek bemutatásával (a folyósító adalékszer nélküli betonreceptúrák nyilvánosságra kerülése nélkül, azok letakarásával): 
- a betonösszetevők jegyzékének,

- a friss beton tömörítési mértékkel és terülési mértékkel kifejezett konzisztencia mérőszámának és osztályának,

- a friss beton tervezett levegőtartalmának és tervezett testsürüségének,

- a friss beton mért testsürüségének,

- a friss beton eltarthatóságának jellemzőinek,

- a megszilárdult beton átlagos nyomószilárdságának, szórásának, testsürüségének,

- a megszilárdult beton egyéb termékminősítő tulajdonságainak, mint például a fagy- és olvasztósóállóság lehetőleg legalább kétféle módszerrel meghatározva, a vízfelvétel, a vízzáróság, a kopásállóság stb. szabványos vizsgálata eredményeinek,

- és az árnak.

3. Az ajánlatkérés második lépése

$\mathrm{Az}$ ajánlatkérés második lépésére akkor van szükség, ha az ajánlatkérés első lépésében a betongyártó által ajánlott folyósító adalékszer nélküli kiindulási beton konzisztenciája földnedvesebb (szárazabb) az elvárt építéshelyi bedolgozási konzisztenciánál.

Ebben az esetben a friss beton szállítási és bedolgozási körülményeinek ismeretében meg kell tervezni:

- a bedolgozandó friss beton elvárt konzisztenciáját tömörítési mértékkel és terülési mértékkel,

- a friss beton tervezett eltarthatóságát, amelyet az eltarthatósági idővel, és az évszakot jellemző hőmérséklettel, esetleg páratartalommal kell megadni (MSZ 4798:2016 szabvány 7.7. szakasza), majd második lépésként ajánlatot kell kérni az elvárt bedolgozási konzisztenciájú folyósítószeres betonra a következő feltételekkel:

- az ajánlatkérés első lépésében megadott összetételü kiindulási betont folyósítani kell oly módon, hogy a folyósító adalékszer nélküli kiindulási beton összetétele a folyósító adalékszertartalmon kívül ne változzon,

- a kiindulási beton folyósítását hatékony, optimális menynyiségben adagolt folyósítószerrel kell megoldani, és úgy, hogy a képlékenyített vagy folyósított beton zsaluzatba bedolgozható konzisztenciájú legyen, és ne legyen például ragadós vagy szétosztályozódásra hajlamos.

A gyártó ajánlatában szerepelnie kell a típusvizsgálat végeredményét tartalmazó jegyzőkönyvek bemutatásával (a folyósító adalékszeres betonreceptúrák nyilvánosságra kerülése nélkül, azok letakarásával):

- a betonösszetevők jegyzékének,

- a friss beton tömörítési mértékkel és terülési mértékkel kifejezett konzisztencia mérőszámának és osztályának,

- a friss beton tervezett levegőtartalmának és tervezett testsürüségének,

- a friss beton mért testsürüségének,

- a friss beton eltarthatóságának jellemzőinek,

- a megszilárdult beton átlagos nyomószilárdságának, szórásának, testsürüségének,

- a megszilárdult beton nyomószilárdsági osztályának (C.../... vagy $\mathrm{C} . . . / . . \mathrm{AC}_{50}(\mathrm{H})$, illetve $\mathrm{LC} . . . / .$. vagy $\mathrm{LC}_{\text {.......AC }}(\mathrm{H})$ ),

- a megszilárdult beton egyéb termékminősítő tulajdonságainak, mint például a fagy- és olvasztósóállóság legalább kétféle módszzerrel meghatározva, a vízfelvétel, a vízzáróság, a kopásállóság stb. szabványos vizsgálata eredményeinek,

- és az árnak.

Megjegyzés: Az ajánlatkérés első és második lépése össze is vonható.

\section{A friss beton átadás-átvétele}

Az ajánlatkérés második lépése eredményeképpen megrendelt friss betont piaci termékként a gyártó a megrendelőnek az MSZ 4798:2016 szabvány alapján, a beton nyomószilárdsága alapján a kiindulási feltételül szabott MSZ EN 1992-1-1:2010, MSZ EN 1992-2:2009 (egyszóval: Eurocode 2) szabvány vagy az MSZ 4798.2016 szabvány „P” melléklete szerint kell átadja.

Az átadás-átvételi eljárás során a próbatesteket az MSZ 4798.2016 szabvány szerint kell elkészíteni, utókezelni és az ott leírtaknak megfelelően vizsgálni.

Az átadás-átvételi eljárás - legkésőbb a friss betonból vett átadás-átvételi próbatestek vizsgálati eredményeinek értékelését követő - végső zárultával a beton sorsát illetően az MSZ 4798:2016 szabvány szerepe véget ér, a továbbiak nem tartoznak az MSZ 4798.2016 szabvány érvényességi körébe (6. ábra).

5. A friss beton monolit-szerkezetbe épitése, szilárditása

A friss beton munkahelyi belső szállítását, monolit-szerkezetbe való bedolgozását (tömörítését), a bedolgozott friss beton utókezelését a betonszerkezetek kivitelezésével foglalkozó MSZ EN 13670:2010 szabvány szerint kell végezni. $\mathrm{Az}$ építéshelyen bedolgozott beton (monolitbeton) utóke-

6. ábra: $A$ beton útja a típusvizsgálattól (próbakeveréstől) a szerkezetbe építésig (igénybevételig), avagy a beton előírt karakterisztikus (jellemző) értékének (fck,cyl, $\varnothing 150 \times 300)$ változása a típusvizsgálat (próbakeverés) és a szerkezetbe építés (igénybevétel) között az MSZ EN $1992-1$-1:2010 (Eurocode 2) és az MSZ 4798:2016 szabvány szerint

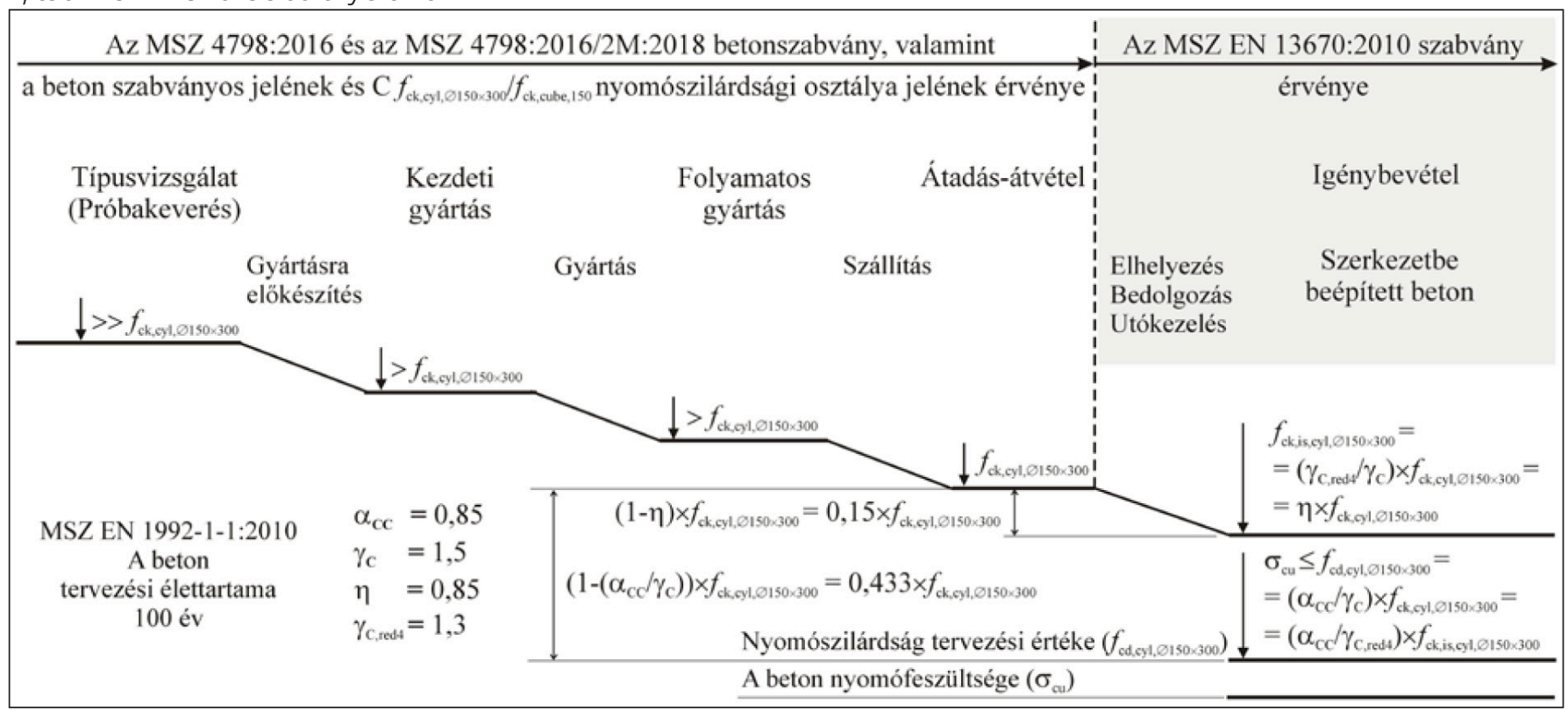


4. táblázat: Az építéshelyen bedolgozott beton (monolitbeton) utókezelésének megkövetelt helyettesítő időtartama (t) a beton szilárdulási ütemének (sebességének) és környezeti osztályának függvényében az MSZ 4798:2016/2M:2018 szabvány NAD Q3. táblázata szerint

\begin{tabular}{|c|c|c|c|c|}
\hline A beton szilárdulási üteme (sebessége) & Gyors & Közepes & Lassú & $\begin{array}{c}\text { Nagyon } \\
\text { lassú }\end{array}$ \\
\hline $\begin{array}{l}\text { A szilárdulási ütem: a beton } 2 \text { és } 28 \text { napos, MSZ 4798:2016 szerinti } \\
\text { átlagos nyomószilárdságának hányadosa: } \mathrm{f}_{\mathrm{cm}, 2} / \mathrm{f}_{\mathrm{cm}, 28}\end{array}$ & $\geq 0,5$ & $0,3 \leq$ és $<0,5$ & $0,15 \leq$ és $<0,3$ & $<0,15$ \\
\hline Környezeti osztály & \multicolumn{4}{|c|}{ Utókezelés megkövetelt helyettesítő időtartama, $t$, nap } \\
\hline XC1, XC2, XC3, XF1, XV1(H), XA1, XA4(H), XK1(H), XV0(H) & 2 & 3 & 4 & 7 \\
\hline Összes többi környezeti osztály & 3 & 7 & 10 & 14 \\
\hline
\end{tabular}

zelésének megkövetelt ideje a beton szilárdulási ütemének (sebességének) és környezeti osztályának a függvényében az MSZ 4798:2016/2M:2018 szabvány NAD Q3. táblázatában található (4. táblázat).

A 4. táblázatbeli megkövetelt helyettesítő időtartamokat akkor kell alkalmazni, ha a napi közepes levegőhőmérséklet nagyobb, mint $+12{ }^{\circ} \mathrm{C}\left(t_{\mathrm{ekv}}=1,0\right)$. Azokat a napokat, amelyeken a napi közepes levegőhőmérséklet $+5^{\circ} \mathrm{C}$ és $+12{ }^{\circ} \mathrm{C}$ közé esik $t_{\text {ekv }}=0,7$ időegyenértékkel, azokat pedig, amelyeken a napi közepes levegőhőmérséklet $0{ }^{\circ} \mathrm{C}$ és $+5^{\circ} \mathrm{C}$ közé esik $t_{\text {ekv }}=0,3$ időegyenértékkel kell számításba venni.

A ténylegesen szükséges utókezelési napok száma az öszszefüggésből határozható meg, ahol $t_{\text {ekv }}$ az $n$-edik utókezelési naphoz tartozó idő-egyenérték és $t$ a 4. táblázatbeli helyettesítő időtartam, mindkettő napban kifejezve. Az utókezelést addig az $u$ napig kell folytatni, amelyiken a fenti követelmény már teljesül.

A Deutscher Beton- und Bautechnik-Verein E.V. a beton utókezeléséről 2019 márciusában adott ki müszaki útmutatót (DBV-Merkblatt, 2019). Ebben egyebek mellett bemutatják az EN 13670 és a ZTV-ING dokumentumnak a monolit-betonok utókezelési idejére vonatkozó ajánlásait is.

6. A szerkezetbe beépitett beton minősége

A friss beton átvételét követő legalább 28 nap múlva, az átadásátvételi betonvizsgálatok eredményeinek birtokában háromféle dolog történhet:

a) Az átadás-átvételi vizsgálati eredmények szerint a megvásárolt beton szilárdsága megfelelő, és ezzel a transzportbeton vagy a helyszínen kevert beton története lezárul, a gyártónak a beton szilárdságáért vállalt felőssége megszünik, a kivitelezőnek nincs a megvásárolt beton minőségével kapcsolatos teendöje;

b) Előfordulhat, hogy az átadás-átvételi vizsgálati eredmények szerint a termékként megvásárolt, ezzel a kivitelező tulajdonába vagy kezelésébe került - már terméket nem képviselő és időközben bedolgozott MSZ 4798:2016 szabvány szerinti friss beton a vonatkozó követelményeket vagy azok egy részét nem teljesíti. Ez a még be nem dolgozott friss betonra mint termékre vonatkozó hibás teljesítés jogi kategóriája. Ebben az esetben az időközben bedolgozott és megszilárdult beton állapotát az alábbi d) pont figyelembevételével meg kell vizsgálni.

c) $\mathrm{Az}$ is előfordulhat, hogy bár az átadás-átvételi vizsgálati eredmények szerint a megvásárolt friss beton tulajdonságai megfelelőek, a beépített beton szilárdsági vagy alaki állapotát a beruházó, a tervező, a müszaki ellenőr vagy maga a kivitelező szemrevételezés alapján mégis megvizsgálni tartja szükségesnek. Aggodalomra például bedolgozási hiá- nyosságok, cementpép kiválások, töppedések, porózus szövetszerkezetü felületek, repedések megjelenése adhat okot.

d) Mind a b), mind a c) pont fennállása esetén első lépés a hibagyanús helyek pontos felmérése, roncsolássmentes nyomószilárdság-vizsgálat és a kismintás szövetszerkezeti (például cementtartalom) vizsgálat elrendelése lehet, amelyek eredménye alapján kell a roncsolásos szilárdságvizsgálathoz való magfúrások szükségességét illetően határozni. A kapott eredmény megfelelőségének vagy nem-megfelelőségének megállapítása a tervező statikus fealadata, aki nem-megfelelőség esetén a szerkezeti rész megerősítését, netán a bontását és újrakészítését is szükségesnek tarthatja. Ilyen gondok megoldásába az érintett szakterületen jártas szakértő bevonása hasznos lehet.

A tartószerkezet megfelelőségét, állékonyságát meghatározandó, a szerkezetbe beépített beton adott korú nyomószilárdsága karakterisztikus (jellemző) értékéből $\left(f_{\text {ck,is,cyl,ø150×300,test }}\right)$ ki kell számítani a beton nyomószilárdsági teherbírásának értékét $\left(f_{\text {cd,cyl,Ø150×300,test }}\right)$ :

$f_{\text {cd,cyl }, 1150 \times 300, \text { test }}=\left(\alpha_{\mathrm{CC}} / \gamma_{\mathrm{C}, \text { red } 4}\right) \times f_{\text {ck,is,cyll,ø150×300,test }}$, ahol:

- $\alpha_{\mathrm{CC}}=$ beton $\sigma_{\mathrm{cu}}$ nyomófeszültségének a tartós szilárdság figyelembevételére szolgáló osztója (MSZ EN 1992-11:2010 szabvány 3.1.6. szakasz (1)P bekezdés és NA2.2.1. szakasz). Értéke a legfeljebb 50 év tervezési élettartamú szerkezetek esetén $\alpha_{\mathrm{CC}}=1,00$, az 50 évnél nagyobb, például 100 év tervezési élettartamú szerkezetek esetén $\alpha \mathrm{cc}=0,85$.

- $\gamma_{\mathrm{C}, \mathrm{red} 4}=$ beton $\sigma_{\mathrm{cu}}$ nyomófeszültsége $\gamma_{\mathrm{C}}$ biztonsági (parciális) tényezőjének csökkentett értéke. A $\gamma_{\mathrm{C}}$ biztonsági (parciális) tényező értéke általában $\gamma_{\mathrm{C}}=1,5$, ennek csökkentett értéke $\gamma_{\mathrm{C} \text {,red } 4}=1,3 \sim \eta \times \gamma_{\mathrm{C}}=0,85 \times 1,5=1,275$, ahol $\eta=0,85$ átszámítási tényezö, amelyet szerkezetbe beépített beton vizsgálata esetén kell alkalmazni.

A szerkezetbe beépített beton nyomószilárdsági teherbírásának így meghatározott értékét $\left(f_{\mathrm{cd}, \mathrm{cyl}, \varnothing 150 \times 300 \text {,test }}\right)$ az igénybevételekböl a betonban ébredő nyomófeszültséggel $\left(\sigma_{\mathrm{cu}}\right)$ összevetve - a nyomószilárdsági osztály meghatározása nélkül - meg lehet állapítani a beépített beton nyomószilárdságának megfelelőségét vagy nem-megfelelőségét (Kausay, 2013).

A követelmény:

$f_{\text {cd,cyl, } 150 \times 300, \text { test }} \geq \sigma_{\text {cu, }}$ ahol, ahogy fenn szerepel, az egyenlőtlenségnek mind a bal, mind a jobb oldala a rend kedvéért az Eurocode 2 szerint vagy az MSZ 4798.2016 szabvány „P” melléklete számított érték.

Arra ügyelni kell, hogy két összhangban nem lévő szabványt egy meghatározás tekintetében vegyesen ne használjunk, továbbá hogy egy egyenleten belül az azokban megjelenített 
fogalmakat az egyenlet bal és jobb oldalán feltétlenül azonosan értelmezzük.

\section{MEGÁLLAPÍTÁSOK, KÖVETKEZ- TETÉSEK}

Jelen cikkben részletesen tárgyaljuk az MSZ 4798:2016, MSZ 4798:2016/1M:2017 és MSZ 4798:2016/2M:2018 szabvány szerint a betonok szabványos jelölését, a betontermékek és betongyártmány fogalmát, a kiindulási és a folyósítószeres beton, valamint az eltarthatóság fogalmát és ezek betontechnológiai vonatkozásait. Bevezettük a fagyasztási veszteség térfogategyenlőségi átszámítási tényezőjét.

A beton szabványos jelölése a beton legfontosabb elérendő tulajdonságait összefoglaló alapvetö, irányt mutató ,,adathordozó", amely a vasbetonépítményt létrehozó beruházó, építtető, szerkezettervező, betontechnológus, betongyár, betonelemgyár, kivitelező és megfelelőségtanúsító között nélkülözhetetlen betontechnológiai kapcsolatot teremt.

Az MSZ 4798:2016 szabvány szerinti betonok szabványos jele a nyomószilárdsági osztály jelét, ha a nyomószilárdsági eredményeket az 50\%-os elfogadási valószínűség alapján értékelik, akkor annak kísérőjelét, a környezeti osztályok, az adalékanyag legnagyobb szemnagysága, a konzisztencia osztály jelét és a szabvány jelzetét kötelezően tartalmazza.

A beton jelében feltételesen - szükség szerint - szerepel, ha könnyübeton, akkor a testsürüségi osztály jele; ha az adalékanyag nem homokos kavics, akkor az adalékanyag megnevezése; ha a betonnak a cement tömegére vonatkoztatott megengedett kloridiontartalma kevesebb mint 0,2 tömeg\%, akkor a megengedett kloridiontartalom jele; a cement és esetleg az aktív, puccolános vagy rejtett hidraulikus tulajdonságú, ún. II. típusú kiegészítőanyag jele; a beton tervezési élettartama, ha az nem 50 év.

A tervezői müszaki leírásban, a betontechnológiai előírásban, illetve a beton megrendelő és szállítási dokumentumában a beton jelén kívül meg kell adni minden olyan követelményt, amelyet az építmény vagy a beton készítésével, illetve átadásátvételével kapcsolatban a beton jelén kívül elöírnak.

A friss betonból vett minták próbatestjeinek vizsgálati eredményei a friss beton tulajdonságait, a megszilárdult betonból vett minták próbatestjeinek vizsgálati eredményei az adott korú megszilárdult beton tulajdonságait jellemzik. A betonok „,Szabványos jele”, „,szabványos jelölése” vagy röviden ,,a beton jele" kizárólag a friss betonok legfontosabb tulajdonságai osztályának megjelölésére szolgál, míg a szerkezetbe beépített betonok tulajdonságai a vizsgálati eredmények átlagos vagy karakterisztikus (jellemző) értékének megadásával írhatók le. Ugyanez vonatkozik a nyomószilárdsági osztály jelére is, amely a beton jelének legfőbb megtestesítője.

Ha a beton szabványos jele szerinti, folyósító adalékszer nélküli beton konzisztenciája földnedvesebb (szárazabb) az elvárt építéshelyi bedolgozási konzisztenciánál, akkor a betonhoz folyósító adalékszert kell keverni. Az ilyen folyósító adalékszer nélkül készülő, de képlékenyítésre, folyósításra nem feltétlenül alkalmas összetételü friss betont kiindulási betonnak nevezzük. A folyósító adalékszer hatásának érvényesüléséhez olykor a kiindulási friss betont a megengedett legnagyobb vízcement tényező megtartása mellett a megkövetelt legkisebb cementtartalom növelésével lágyítani szükséges.

A megfelelő építéshelyi bedolgozási konzisztenciát a betontechnológiai munkamenetterv alapján kell megtervezni.

\section{HIVATKOZOTT SZAKIRODALOM}

Balázs L. Gy. - Kausay T. (2018), „Betontípusok, fogalmak, jelölések, újdonságok. Az MSZ 4798:2016, MSZ 4798:2016/1M:2017 és MSZ 4798:2016/2M:2018 betonszabvány néhány fejezetének értelmezése", Vasbetonépités, XX. évfolyam 2018/1. szám, pp. 16-22.

Bonzel, J. - Dahms, J. (1978), „Über den Wasseranspruch des Frischbetons”, beton, Jg. 28 (1978), Heft 9. pp. 331-336, Heft 10. pp. 362-367., Heft 11. pp. 413-416.

Bonzel, J.-Siebel,E. (1973), „Fließbeton und seineAnwendungsmöglichkeiten”, Vortrag auf der Technisch-wissenschaftlichen Zementtagung am 14.9.1973 in München, https://www.vdz-online.de

DBV Deutscher Beton-Verein (1995), „Beton-Handbuch. Leitsätze für Baü̈berwachung und Bauausführung", 3., neubearbeitete Auflage, $D B V$ Deutscher Beton-Verein, Wiesbaden, 1995.

Faust, Th. (2003), „Leichtbeton im konstruktiven Ingenieurbau. BauingenieurPraxis", Ernst \& Sohn Verlag GmbH, Berlin, 2003. DOI: 10.1088/1757899X/246/1/012003

Grübl, P. - Weigler, H. - Karl, S. (2001), „Beton. Arten, Herstellung und Eigenschaften", Ernst \& Sohn Verlag GmbH, Berlin, 2001.

Kausay T. (2006), „A friss beton konzisztenciája”, Vasbetonépités, VIII. évfolyam 2006/4. szám, pp. 106-115.

Kausay T. (2013), „Beton. A betonszabvány néhány fejezetének értelmezése. Oktatási és továbbképzési kiadvány", Mérnöki Kamara Nonprofit Kft., Budapest, 2013.

Kern, E. - Koch, H.-J. (1976), „Anwendung von Fließbeton”, Betonund Stahlbetonbau, Jg. 71. (1976), Heft 12. pp. 285-289. https://doi. org/10.1002/best.197600580

Koch, K. - Würth, E. (1971), „Wasseranspruchs- und Stoffraumrechnung für Beton", beton, Jg. 21 (1971), Heft 8. pp. 342-347.

König, G. - Viet Tue, N. - Zink, M. (2001), „Hochleistungsbeton. Bemessung, Herstellung und Anwendung”, Ernst \& Sohn Verlag GmbH, Berlin, 2001.

Müller, H. S. - Reinhardt, H.-W. (2009), „Beton”, Beton-Kalender, Jg. 98. (2009), Band 1., pp. 1-150., Ernst \& Sohn Verlag GmbH, Berlin, 2009. https://doi.org/10.1002/9783433600344.ch1

Röhling, S. - Eifert, H. - Jablinski, M. (2012), „Betonbau. Band 1. Zusammensetzung, Dauerhaftigkeit, Frischbeton", Fraunhofer IRB Verlag, Stuttgart, 2012.

Springenschmid, R. (2007), „Betontechnologie für die Praxis”, Bauwerk Verlag $\mathrm{GmbH}$, Berlin, 2007.

Ujhelyi J. (2205), „Betonismeretek”, Müegyetemi Kiadó, Budapest, 2005.

Wesche, K. (1993), „Baustoffe für tragende Bauteile. Band 2: Beton, Mauerwerk (Nichtmetallisch-anorganische Stoffe) Herstellung, Eigenschaften, Verwendung, Dauerhaftigkeit", Bauverlag GmbH, Wiesbaden und Berlin, 1993. https://doi.org/10.1007/978-3-322-80187-6

Wierig, H.-J. - Restorff, B. (1989), „Einfluß verschiedener Zemente und unterschiedlicher Frischbetontemperaturen”, tanulmány a „Konsistenz und Ansteifen des Frischbetons (1)" című kiadványban. Schriftenreihe des Bundesverbandes der Deutschen Transportbetonindustrie, 4. Beton-Verlag $G m b H$, Düsseldorf, 1989

Wierig, H.-J. - Restorff, B. (1990), „Einfluß verschiedener Betonverflüssiger”, tanulmány a „Konsistenz und Ansteifen des Frischbetons (2)" címü kiadványban. Schriftenreihe des Bundesverbandes der Deutschen Transportbetonindustrie, 6. Beton-Verlag GmbH, Düsseldorf, 1990.

Wierig, H.-J. - Restorff, B. (1998), „Vergleichende Untersuchungen unter Labor- und großtechnischen Bedingungen”, tanulmány a „Konsistenz und Ansteifen des Frischbetons (3)" címü kiadványban. Schriftenreihe des Bundesverbandes der Deutschen Transportbetonindustrie, 10. Verlag Bau+Technik GmbH, Düsseldorf, 1998.

Zement-Merkblatt B 20 (2017), „Zusammensetzung von Normalbeton Mischungsberechnung", Bundesverband der Deutschen Zementindustrie e.V. Köln, 2017

\section{HIVATKOZOTT RENDELE- TEK, SZABVÁNYOK, MÜSZAKI ELÖÍRÁSOK, IRÁNYELVEK ÉS SPECIFIKÁCIÓK}

1993. évi X. törvény „A termékfelelősségről” Magyar Közlöny 1993. évi 24. szám. (1993. március 2.) A törvényt a 2013. évi CLXXVII. törvény 67. § e) pontja hatályon kívül helyezte 2014. március 15 . napjával.

3/2003. (I. 25.) BM-GKM-KvVM együttes rendelet „Az építési termékek müszaki követelményeinek, megfelelőség igazolásának, valamint forgalomba hozatalának és felhasználásának részletes szabályairól”. Magyar Közlöny. 2003. évi 8.szám. 2013.07.01-én érvényét vesztette és helyébe lépett az Európai Parlament és a Tanács 305/2011/EU rendelete

2013. évi CLXXVII. törvény „A Polgári Törvénykönyvről szóló 2013. évi V. törvény hatálybalépésével összefüggő átmeneti és felhatalmazó rendelkezésekről” Magyar Közlöny 2013. évi 185. szám. (2013. november 8.) 
DBV-Merkblatt „Nachbehandlung von Beton”. Deutscher Beton- und Bautechnik-Verein.E.V. Berlin, 2019.

MSZ EN 206-1:2002 „Beton. 1. rész: Müszaki feltételek, teljesítőképesség, készítés és megfelelöség" Visszavont szabvány

MSZ EN 206:2014 „Beton. Müszaki feltételek, teljesítőképesség, készítés és megfelelőség" Visszavont szabvány

MSZ EN 206:2013+A1:2017 „Beton. Müszaki feltételek, teljesítőképesség, készítés és megfelelőség"

MSZ EN 1992-1-1:2010 „Eurocode 2: Betonszerkezetek tervezése. 1-1. rész: Általános és az épületekre vonatkozó szabályok"

MSZ EN 1992-2:2009 „Eurocode 2: Betonszerkezetek tervezése. 2. rész: Betonhidak. Tervezési és szerkesztési szabályok"

MSZ EN 13369:2013 „Előre gyártott betontermékek általános szabályai”

MSZ EN 13670:2010 „Betonszerkezetek kivitelezése”

MSZ EN 13877-1:2013 „Betonburkolatok. 1. rész: Anyagok”

MSZ CEN/TS 12390-9:2018 „A megszilárdult beton vizsgálata. 9. rész: Fagyállóság jégolvasztó sóval. Lehámlás”

MSZ 4798-1:2004 „Beton. 1. rész: Müszaki feltételek, teljesítőképesség, készítés és megfelelőség, valamint az MSZ EN 206-1 alkalmazási feltételei Magyarországon" Visszavont szabvány

MSZ 4798:2016 „Beton. Müszaki követelmények, tulajdonságok, készítés és megfelelőség, valamint az EN 206 alkalmazási feltételei Magyarországon"

MSZ 4798:2016/1M:2017 „Beton. Müszaki követelmények, tulajdonságok, készítés és megfelelőség, valamint az EN 206 alkalmazási feltételei Magyarországon"

MSZ 4798:2016/2M:2018 „Beton. Müszaki követelmények, tulajdonságok, készítés és megfelelőség, valamint az EN 206 alkalmazási feltételei Magyarországon"

MI-04-562:1992 „Transzportbeton” Építésügyi ágazati müszaki irányelv

MÉASZ ME-04.19:1995 műszaki elöírás 4. fejezete „A beton”, Magyar Épitöanyagipari Szövetség, Budapest, 1995.

e-UT 06.03.31:2017 „Beton pályaburkolatok építése. Építési előírások, követelmények", Útügyi müszaki elöírástervezet, Magyar Út- és Vasútügyi Társaság, Budapest, 2017. Az e-UT 06.03.31:2017 útügyi mủszaki elöírástervezet előzménye: ÚT 2-3.201:2006.

e-UT 0701.21:2016 „Közlekedésépítési célú, előregyártott könnyübeton tartószerkezeti elemek tervezése és gyártása”, 32. Tervezési útmutató, Magyar Út- és Vasútügyi Társaság, Budapest, 2016.

ZTV-ING ,Zusätzliche Technische Vertragsbedingungen und Richtlinien für Ingenieurbauten. Teil 1-10: Massivbau. 2017.
Dr. Balázs L. György (1958) okl. építőmérnök, mérnöki matematikai szakmérnök PhD, Dr. habil., egyetemi tanár, a müszaki tudomány kandidátusa. BME Építőanyagok és Magasépítés Tanszék. Fő kutatási területei: beton, vasbeton és feszített vasbeton szerkezetek (anyagai, laboratóriumi vizsgálata és modellezése), roncsolásmentes vizsgálatok. Speciális betonok és betétek: szálerősítésű betonok (FRC), nem acélanyagú (FRP) betétek, megerősítések anyagai és módjai, HPC, UHPC, LWC. Tüzállóságra való tervezés, tűzállóság fokozása. Fagyállóság fokozása. Kémiai ellenállóképesség fokozása. Tartósság. Használati élettartam. Erőátadódás betonban, vasbeton tartók repedezettségi állapota. Fáradás. Lökésszerü terhelés. Nukleáris létesítmények. A fib (Nemzetközi Betonszövetség) elnöke (2011-2012), jelenleg tiszteletbeli elnöke. A fib Magyar Tagozat elnöke. Az Int. PhD Symp. in Civil Engineering alapítója. A fib Com 9 ,Dissemination of knowledge” elnöke.

Dr. Kausay Tibor (1934) okl. építőmérnök (1961), vasbetonépítési szakmérnök (1967), egyetemi doktor (1969), a müszaki tudomány kandidátusa (1978), Ph.D. (1997), címzetes egyetemi docens (1985), címzetes egyetemi tanár a BME Építőanyagok és Magasépítés Tanszéken (2003), a fib Magyar Tagozat tagja (2000), az MTA gróf Lónyay Menyhért emlékérmese (2003), a Palotás László-díj birtokosa (2015). Tevékenysége a betontechnológiai és a kő- és kavicsipari kutatásra, fejlesztésre, szakértésre, oktatásra, szabványosításra terjed ki. Publikációinak száma mintegy 220.

CONCRETE TYPES, TERMINOLOGY, NOTATIONS, ACTUALITIES Specifications to some of the chapters of the concrete standards MSZ 4798:2016, MSZ 4798:2016/1M:2017 and MSZ 4798:2016/2M:2018 PART 2. CONCRETE GRADE, CONCRETE PRODUCT, CONSISTENCY, CONCRETE TECHNOLOGY ASPECTS

György L. Balázs - Tibor Kausay

MSZ EN 206-1:2002 Standard is substituted by MSZ EN 206:2014 and MSZ EN 206:2013+A1:2017. These required the change of MSZ 4798-1:2004 Hungarian National Application Document for MSZ 4798:2016 and MSZ 4798:2016/1M:2017 by considering recent aspects of concrete technology and further specified in MSZ 4798:2016/2M:2018.

Present series of articles are about the modifications of concrete standards in the period of 2014 to 2018 in Hungary. This article is the second part of the series. The first part of the series has been pulished in VASBETONÉPÍTÉS Vol. XX. issue 2018/1. pp. 16-22. (Balázs L. - Kausay, 2018/1). 